Florida International University FIU Digital Commons

4-16-1987

\title{
Computer interaction : its effect on attitude and performance in older adults
}

Jane Ansley

Florida International University

DOI: $10.25148 /$ etd.FI14032324

Follow this and additional works at: https://digitalcommons.fiu.edu/etd

Part of the Psychiatry and Psychology Commons

\section{Recommended Citation}

Ansley, Jane, "Computer interaction : its effect on attitude and performance in older adults" (1987). FIU Electronic Theses and Dissertations. 1292.

https://digitalcommons.fiu.edu/etd/1292

This work is brought to you for free and open access by the University Graduate School at FIU Digital Commons. It has been accepted for inclusion in FIU Electronic Theses and Dissertations by an authorized administrator of FIU Digital Commons. For more information, please contact dcc@fiu.edu. 


\title{
ABSTRACT
}

COMPUTER INTERACTION: ITS EFFECT ON ATTITUDE AND PERFORMANCE IN OLDER ADULTS

\author{
BY \\ Jane Ansley
}

This study examined the interaction of age, attitude, and performance within the context of an interactive computer testing experience. Subjects were 13 males and 47 females between the ages of 55 and 82 , with a minimum of a high school education.

Initial attitudes toward computers, as measured by the Cybernetics Attitude scale (CAS), demonstrated overall equivalence between these older subjects and previously tested younger subjects. Post-intervention scores on the CAS indicated that attitudes toward computers were unaffected by either a "fun" or a "challenging" computer interaction experience.

The differential effects of a computerized vs. a paperand-pencil presentation format of a 20-item, multiple choice vocabulary test were examined. Results indicated no significant differences in the performance of subjects in the two conditions, and no interaction effect between attitude and performance.

These findings suggest that the attitudes of older adults towards computers do not affect their computerized testing performance, at least for short term testing of verbal abilities. A further implication is that, under the 
2

conditions presented here, older subjects appear to be unaffected by mode of testing. The impact of recent advanced in technology on older adults is discussed.

Professor Joan Ember 
COMPUTER INTERACTION:

ITS EFFECT ON ATTITUDE AND PERFORMANCE IN OLDER ADULTS

by

Jane Ansley

A thesis submitted in partial fulfillment of the

requirements for the degree of

MASTER OF SCIENCE

in

PSYCHOLOGY

at

FLORIDA INTERNATIONAL UNIVERSITY

Committee in charge:

Professor Joan Erber Chairperson

Professor William Kurtines

Professor Marvin Dunn

August, 1987 
To Professors: Dr. Joan Erber

Dr. William Kurtines

Dr. Marvin Dunn

This thesis, having been approved in respect to form

and mechanical execution, is referred to you for judgment upon its substantial merit.

Dean James Ȧ. Mau, Ph/D.

College of Arts and Sciences

The thesis of Jane Ansley is approved.
William Kurtines, Ph.D.

Professor

Marvin Dunn, Ph.D.

Professor

Joan Erber, Ph.D.

Major Professor

Date of Examination: April 16, 1987 
COMPUTER INTERACTION:

ITS EFFECT ON ATTITUDE AND PERFORMANCE IN OLDER ADULTS

by

Jane Ansley

A thesis submitted in partial fulfillment of the requirements for the degree of

MASTER OF SCIENCE

in

PSYCHOLOGY

at

FLORIDA INTERNATIONAL UNIVERSITY 
TABLE OF CONTENTS

LIST OF TABLES..................... v

INTRODUCTION. . . . . . . . . . . . . . . . . . I

Information Control and the Aged in Society........ I

Technological Literacy................... 4



The Role of the Computer.................. 9

The Pace of Technological Societies.............13

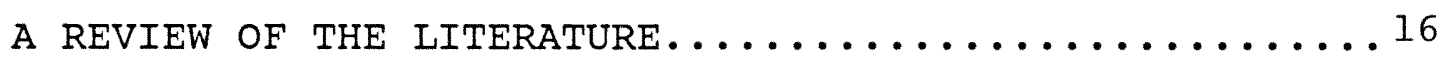

Attitudes Toward Computers................... 16

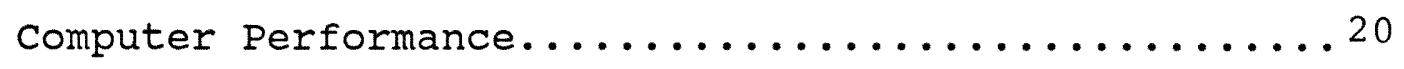

Education-C.A.I. (Computer Assisted Instruction) ....22

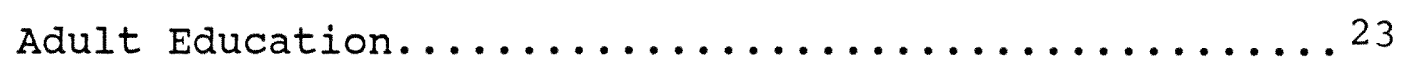

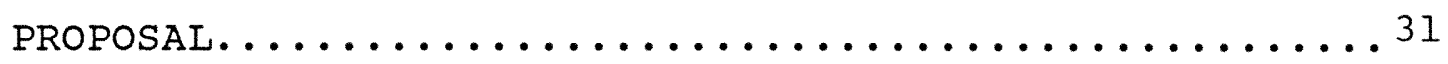

Hypotheses..............................

Hypothesis 1

Hypothesis 2

Hypothesis 3

Hypothesis 4

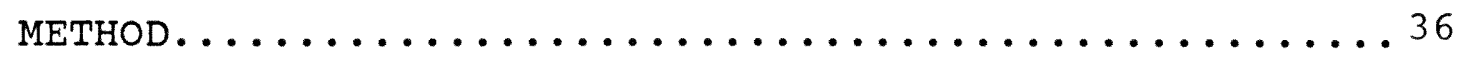


subjects......................... ${ }^{36}$

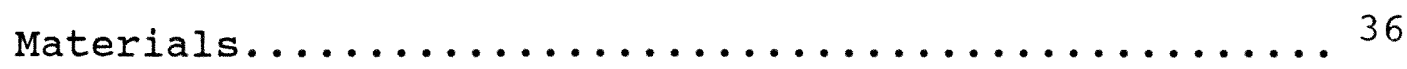

The Cybernetics Attitude Scale

Machine Experience Survey

The "Vocabulary Quiz" Computer Software Program

The "Vocabulary Quiz" Paper-and-Pencil Version

The "What's For Lunch" Computer Software Program



Treatment 1: Computer Quiz Group

Treatment 2: Paper-and-Pencil Quiz Group

Treatment 3: Computer Fun Group

RESULTS.

50

Pilot Study-Young/old Comparison on the CAS

Attitude scale.......................... 50

Description of older Adult Treatment Groups........ 50

Testing the Hypotheses of the study............. 51

Hypothesis 1

Hypothesis 2

Hypothesis 3

Analysis of Gambling Features................. 54

Subject's Method of Testing Prefernce........... 56

Analysis of Machine Experience survey........... 57

Hypothesis 4

DISCUSSION......................... 60

Attitudes Toward Computers................. 60 
Attitudes and Performance................... 62

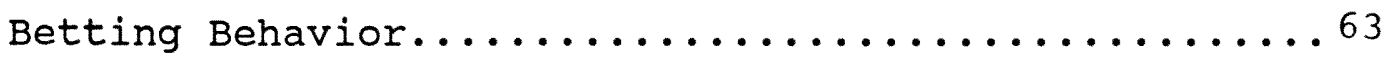

Subjects Method of Test Preference.............65

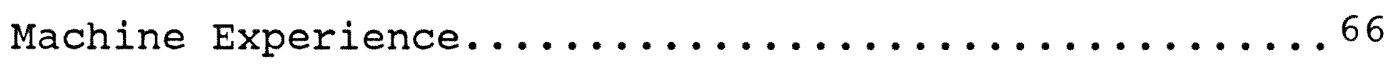

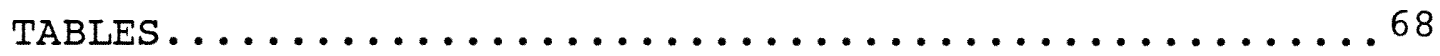

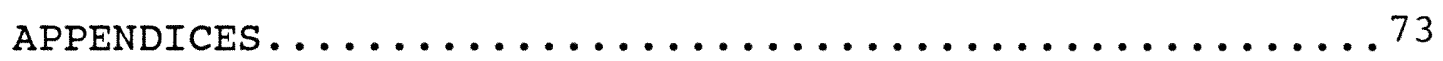

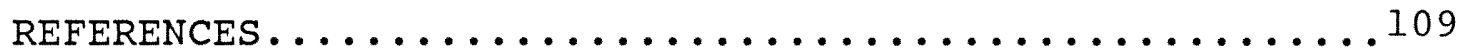

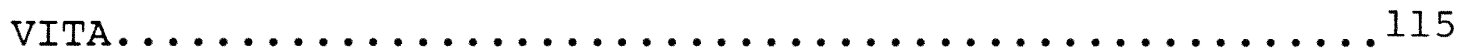




\section{LIST OF TABLES}

1. Means and Standard Deviations for Three Sample Groups on the Ten Subscales and Total Scores Comprising the Computer Attitude



2. Mean Scores for Demographic Variables for Each Treatment...............69

3. Mean Performance Scores for for Each Treatment..................... 70

4. Subjects' Method of Testing Preference for Each Treatment............... 71

5. Description of Machine Experience for the study sample................... 72 


\section{INTRODUCTION}

Information Control and the Aged in society

The way in which a given society stores, maintains, and controls its informational resources, has certain implications for the functioning of different age groups within that society (Rue, 1973). Maxwell and Silverman (1970) provide an analysis of the implications of information control for aged groups within modern, industrialized societies. They explore the connection between the perceived value of aged individuals within a given society, relative to the degree of control those individuals exert over the information necessary for the maintenance of that society. Their perspective is illustrated best by briefly contrasting primitive societies with modern, industrialized societies.

In primitive societies, without sophisticated means of information storage, the aged members of the community serve as functional depositories, storing the information necessary for the maintenance of the culture, and retrieving it as required. The elders are often the only source for information concerning myths, legends, ethical principles and customs. They may even be the keepers of certain "secret" pieces of information that only a few individuals have access to. These societies tend to be stable and to change very slowly. 
In contrast to this is the modern, industrialized society, in which sophisticated methods of information storage combine with a rate of information turnover so fast that much of the current information store is rendered obsolete in a matter of a few years. In this type of society, according to Maxwell and Silverman, whatever information the older person initially controls in young adulthood rapidly becomes obsolete. The information becomes useless to the current society on an operational level, and, since the old information is recorded in documents, books and other permanent information stores, the individual is unnecessary even for historical purposes. With the loss of information control, the older person necessarily is less involved in the social situations within which transfer of information occurs; activities such as consulting, decision making, arbitrating, entertaining and teaching. Without interactive participation in society, the older individual is, quite accurately, viewed as less important for the maintenance and survival of that society. Consequently, the esteem accorded to older individuals, and to the aged as a group, is greatly diminished. According to these authors, the least estimable members of industrialized societies are the aged, who control only obsolete information, and the very young, who don't control enough information. This is, perhaps, an accurate analysis of the role aged individuals fulfill in this society. 
Rue (1973) offers the slightly different viewpoint that this process of informational obsolescense doesn't affect only the aged members of modern societies. He suggests it is a pervasive phenomenon, and that the process is beginning to occur increasingly early in the life cycle of the average adult.

According to Rue, the process of information loss begins as one enters a particular occupation, and formal education essentially comes to an end. As the years go by, to the extent that one continues to draw only on the original information stores acquired in the formal educational process, one's information base becomes increasingly obsolete. Rue points out that there is an inevitable relationship between informational obsolescence and human obsolescence. He speculates that as long as one recognizes and accepts the fact that one's information is obsolete, one can select a successful strategy for life; choosing to either fill the information gaps by acquiring more education, or to just accept the inevitable ceiling (in terms of career and promotions) that will be reached without further education. Rue suggests that, either way, it is possible to attain life satisfaction.

This point of view characterizes the problems surrounding the control of society's informational resources, as a situation affecting adults throughout the life cycle. No special interest in the aged is required to justify attempts to address the very real problems 
highlighted here. In other words, avoidance of informational obsolescense is of concern to all individuals.

\section{Technological Literacy}

What it means to be a literate member of a given society is defined by the requirements for competent functioning within the prevailing culture. It is commonly understood that different societies have different standards for literacy, and that the standards within a given society change.

At the present time it appears that a readjustment of the standards for literacy may be taking place in this society. Aron (1982) suggests that a new requirement for minimal literacy is being imposed: the ability to interact on a rudimentary level with a computer.

Current trends in the field of education indicate that this suggested addition to the definition of literacy is already being implemented. A recent report (Livingston, 1986) filed by the United States Secretary of education, William Bennett, concerning the status of elementary education in this country, included a recommendation that all elementary age children gain a basic grasp of computers. If the presence of computers in the classroom is any indication, it would appear that many school districts are already acting upon secretary Bennetts' suggestion. 
At the college level, according to an article in the New York Times (Fiske, 1985), there is a new wave of curriculum changes occurring in colleges and universities across the country. Not only are students taking more science, math and computer courses, but educators are also bringing the study of technology into the standard liberal arts curricula. According to the article, computer literacy is now a requirement for graduation from many colleges and universities.

One group of researchers (Jaycox and Hicks, 1976) have suggested that it is necessary for older adults to attain "at least a minimal understanding of a computer's role in their lives - from its control of social security and medicare payments to its function in the education of their grandchildren." These researchers also emphasized that it is important for older adults to understand the human element in the computer field, for instance, by realizing that people, not machines, do the programming. (More will be said about the programs designed by these researchers in the section on Adult Education.)

of course, the merger of computers with society has not been accomplished by a smooth process, and in the educational field especially there is resistance to the new technology. The same New York Times article mentioned earlier, which discussed the changes taking place in curricula at colleges and universities, pointed out that at some universities courses designed to teach students about 
technology ended up as vehicles for social scientists to attack technology. Even through anecdotal observation one readily encounters frequent references to the "problems" caused by computers in our everyday lives, comments made by individuals from all walks of life.

It makes sense to examine the source of such resistance to technology. It has been shown that older adults prefer familiar methods of testing (Commission on Non-Traditional Study, 1973) and that they demonstrate a reluctance to take risks in laboratory situations (Botwinick, 1966). Therefore, there is some reason to expect that older adults may demonstrate more resistance than others, although there presently is no research evidence to that effect. However, Aron (1982) suggests that for many people, particularly adults educated before the recent advances in technology, computer interactions require "a discipline in the organization of thought that many adults are unaccustomed to." The rigid rules with which computers operate including branching, sequencing and sequential logic must not only be understood, but accepted. For many, computer operations require a fundamentally new way of thinking.

one author (Turkle, 1985), who engaged in a six year study of the effect of computers on children and young adults in this country, found support for Aron's position. She suggests that the generation of children now growing up with computers from the start may be formulating an entirely new understanding of the nature of technology. Whereas even 
the most committed of adult computer devoteees would characterize the computer as nothing more than an efficient tool, Turkel reports (based on her interviews with children) that the younger generation tends to identify the computer as more human-like, and to see that the machine has much in common with themselves. She relates various annecdotes to illustrate this point, such as that of the young adult college students' descriptions of the human mind as "pure program", thereby attributing the qualities of the machine to themselves.

It remains to be seen whether the observations made by Aron and Turkle, and others like them, concerning the influence of computer technology on society will be realized in the future. For the present, however, the importance that everyone gain a certain degree of technological fluency is apparent. In order to gain control of the informational resources of society, one must be able to demonstrate competence in handling the technological hardware basic to the access of information. For the older adult in particular Danowski and Sacks (1980) have suggested this as a necessary condition for avoiding informational obsolescence.

The proposal that follows will examine the attitudes of older adults towards computers. The design also includes an intervention that will determine whether attitudes toward computers are affected by a hands-on experience with a computer. Two types of computer experience (fun and 
challenging) will be compared, in terms of the differential effects on attitudes toward computers. Also included in the proposal is a comparison of actual performance on the challenging task, using the same materials in both the computer condition and in the paper-and-pencil condition. 
TECHNOLOGY AND THE AGED

\section{The Role of the computer}

The recent advances in communication technology are probably most responsible for the ever-increasing pace of information gathering, modification, and turnover that we are faced with today. Our primary source of information gathering as individual consumers used to occur via the mass media. We all received the same message, more or less, at the same time. The messages were most likely to be paced for the young consumer, and geared specifically to their interests. The situation has apparently changed.

Danowski and Sacks (1980) have suggested that this society has now passed through the era of the mass media, and is now entering the era of the micro media. Instead of everyone being subjected to the same unalterable message via communication systems such as television and radio, individuals are now gaining control over the messages they choose to receive. Technological advances such as VCR's and interactive televisions come to mind, but certainly no other tool reflects this trend more accurately than the personal computer.

In 1973, when the computer industry was in technological infancy, Ramm and Gianturco (1973) made constructive suggestions concerning ways in which the new technological advances in the computer industry could be 
applied to the everyday lives of older people. They envisioned a future full of promise, where applied technology would enable the older population to access housing, transportation and medical information, order groceries and also report on their daily well-being, via computers.

Ten years later, Hoot and Hayslip (1983) noted that the technological revolution had by-passed older adults. They based their conclusion on evidence that the computer industry fails to market products (both hardware and software) toward the older consumer. Hoot and Hayslip concluded that older adults are perceived by the computer industry as unable and unwilling to learn new technology, physically limited in the performance skills required for computer use, and unable to afford the products. Research evidence was presented which clearly demonstrated that some of these perceptions of older adults, if they do exist, represent misconceptions. Studies demonstrating that older adults can acquire the types of skills presumably related to working with computers, such as understanding patterns in letters and numbers and drawing inferences about relationships between sequential patterns of figures (Bleiszner, Willis and Baltes, 1982; Willis, Bleiszner and Baltes, 1982; Plemons, Willis and Baltes, 1978) were cited. In terms of physical limitations in the elderly, Hoot and Hayslip discussed possible problems the older individual may experience with computer keyboards due to poor manual 
dexterity (either because of arthritis or other age-related motor difficulties), eyesight problems and/or lack of experience with a keyboard. These authors emphasized the importance of modifying software programs and hardware to accomodate the older computer user. However, it appears that in the near future these types of potential limitations will be far less significant than Hoot and Hayslip imagined. Time consuming and error-prone keyboard operations have long been recognized by the computer industry as a serious limitation to the computer's well deserved reputation for efficiency and speed. According to several sources, (Meirhenry, 1982; Hofferber, 1986), the next big advance in computer technology will occur with the advent of voice entry data processing. One company, Kurzweil Industries, expects to introduce a product to the retail market in early 1987 that will have a voice-activated word processor that takes dictation at 150 words per minute, with a 15,000 word vocabulary. In light of this innovation, the physical limitations of the aged should lose their prominence as potential drawbacks to working with computers.

To determine whether older people are able to afford computers and are willing to purchase them, the extent to which older people are purchasing and using computers needs to be examined. That the computer industry is overlooking a valuable market in the elderly consumer is revealed in a review article (Dickerson and Gentry, 1983) comparing adoptors to non-adoptors of home computers. These 
researchers reported that adoptors were most likely to be middle-aged, and that 5\% of all adoptors were over the age of 56. Since older consumers do purchase computer software and hardware, this provides direct evidence that older adults are willing and able to purchase and handle the new technology. That so-called "senior citizens" are forming computer clubs to exchange ideas and new product information ("Computers Snare", 1985) suggests that the computer phenomenon has sparked the interest of older individuals as much as their younger counterparts.

Recently, there have been some signs that retailers are recognizing older adults as a largely untapped market of potential consumers for their products and services. This trend can be observed by noting the growing number of advertisements which feature older adult models. The images that are projected present idealized notions of aging, just as the advertisements aimed at younger consumers present images of the perfection of youth.

In a recent article, Mertz and Stephens (1986) propose strategies for marketing to older consumers. Their article was based on an analysis of previous studies drawn from various areas of the aging literature. They concluded that the kind of marketing strategy most likely to succeed with an older age group would: attempt to reduce the risks associated with the purchase of the product or service (e.g. a generous return policy), tend to encourage or reward cash basis purchases, provide product demonstrations prior to 
purchase, and arrange to "piggyback" old familiar products and services to the purchase of newer products and services.

All things considered, it appears that the time is right for older adults to enter the world of computer technology, and perhaps to do so at their own pace. The opportunity is there for them to regain access to and control of the informational resources of society. Certainly, the experiences available by way of interactive computers may be one avenue worth exploring.

\section{The Pace of Technological societies}

Much has been said in recent years about the fast pace of life that has evolved in modern industrialized societies. Many activities of daily life, although not requiring a speedy performance, certainly place a premium on speed. Responding quickly to traffic signals, passing through turnstiles rapidly and accomplishing one's business at the automated bank terminal with a minimum of delay for the next person waiting in line, are all actions highly valued by the average citizen. The impatience of younger people exhibited toward older, usually slower, people in these every day situations can be frequently observed. There seems to be almost a certain standard of acceptable performance speed, understood and shared in common by younger individuals, that many older individuals do not appear to observe. 
In designing the living environments of older people, careful planning may make allowance for slower response times. However, it can't be assumed that the special needs of older people are taken into consideration in the planning of environments frequented by everyone.

Overall, an argument can be made for a built-in age bias in many of the activities required for daily living, whether by actual design or the commonly understood standards of the community. This observation can be conservatively summed up as characterizing modern industrialized societies as geared for the young.

A good example of what is meant by a built-in age bias can be found in the field of computer technology. Consider a situation wherein two groups of subjects, young and old, are asked to perform a number of tasks taken from prepackaged computer software games and instructional materials. Undoubtedly, the older subjects would not perform as well as a group compared with the younger subjects. At first, this might appear to support the conclusion that a learning decrement occurs with increased age. Under closer examination, however, one could point out that the programs used were, almost certainly, designed with young consumers in mind. If they had been designed for older people, perhaps the images would have been larger, the pace slower and the format less ambiguous. Also, the settings and content of the programs, which typically tend to feature space monsters, race cars and other "young" 
images, might have featured instead images geared to the tastes of older individuals. One would also consider the previous experience of the subjects. The younger ones probably would have used a computer before in school or at home. The older subjects may very well have been experiencing a computer for the first time. In other words, the abilities the subjects brought to the situation may have little to do with biological age. Finally, in examining the scores earned, the older subjects would probably have a greater range of scores, since there is much more interindividual variability in this age group. The very poor performances of some of the older subjects would, therefore, have tended to lower the average score for this group.

Taking into consideration the discussion above, concerning the built-in age bias arising from the pace of society, it can be stated that, with reference to the area of computer technology, the aged may be at a disadvantage in today's world. At the very least, the foregoing discussion suggests that the effect of technology on older individuals in this society should be of interest to researchers. 


\section{A REVIEW OF THE LITERATURE}

\section{Attitudes Toward computers}

Stereotypical attitudes toward the aged are frequently encountered in such common cultural platitudes as "You can't teach an old dog new tricks". It is not surprising, therefore, that researchers pioneering in their attempts to introduce computer technology to older adults expected to encounter attitude problems.

One group of researchers (Krauss, et al., 1983) found evidence that there are age-related differences in attitudes toward computers. They administered an attitude questionnaire (number of items and content not available) to 22 individuals who were about to be retired company employees and their spouses, (mean age of 58.8, range not given). Subjects had varying degrees of experience with computers and other business machines. Not surprisingly, those who had worked with computers were less likely than non-users to say that computers are too difficult to use, and that they would avoid them if possible. However, there was also a correlation between age and attitude. The younger older adults exhibited more positive attitudes toward computers than the older ones.

Weisman (1983) introduced simple, interactive computer games to nursing home patients (average age of 85), and found that $80 \%$ of the residents approached were willing to 
attempt the games, and $100 \%$ of those who participated came back to play again. She presented modified (for speed, size of visual image, etc.) versions of games available to consumers, and selected those games appearing to have the most ecological validity (e.g. simulated card playing). It is not surprising, considering the dependency inherent in the living situation of the subjects, that Weisman attributed the success of this project to feelings among the residents that through the computer interactions they were able to master and control an aspect of their environment. Condreay (1984) carried out a similar project, also using nursing home residents, and reported similar results.

By successfully introducing computers to the oldest and frailest segment of the elderly population, the studies clearly suggest an even greater potential for computer interaction with younger cohorts of older adults, and that perhaps attitude may not be as great an obstacle as might be supposed.

Working with a group of independently living older adults, all resident of a retirement hotel, Danowski and Sacks (1980) made computer games available to the residents by incorporating the game into the ongoing recreational activities of the hotel. They also administered a pre- and post-treatment attitude questionnaire which contained five questions (e.g., "Do you have confidence in computers?") to which respondents answers "yes or "no". Unfortuately, the questionnaires were rendered unusable since not enough 
subjects were available for the post-test. However, some trends were observed and reported. Following the computer interaction, attitudes reflecting self confidence increased, there were fewer feelings of loneliness, there was an increase in the desire to "play" with the computers and a tendency to see computers as more helpful to the elderly. In the absence of actual data, however, this research is only suggestive for future work.

one researcher has developed a scale which directly examines attitudes toward computers. The cybernetics Attitude Scale (CAS) (Wagman, 1983) is a 100 item multiplechoice instrument that examines attitudes toward the use of computers in each of ten sectors of society, as defined by Wagman. The ten sectors, each representing a subscale of the instrument, are labeled as follows: society, values, cognition, counseling, medicine, criminal justice system, finance and banking, mathematics and statistics. The instrument yields a total score which indicates an overall attitude (positive or negative) toward the use of computers in each of the ten specified sectors of society.

Using a college age population, Wagman found that his subjects had favorable attitudes toward the use of computers in sectors of society such as the criminal justice system and mathematics, but they did not support the use of computers in sectors such as counseling and medicine. Considering the extensiveness with which this scale examines attitudes toward computers, it would be worthwhile to 
administer this same scale to older subjects for direct comparison to the responses of the young.

An interesting conceptualization of the interaction between the older adult and computers can be formulated from one area of consumer research. Hirschman (1980) proposed that there are actually three levels of consumer-to-product interaction. The "non-adoptor" is a consumer who never gains awareness of a particular product, and therefore never acquires the product. The "vicarious-adoptor" gains awareness of the product and may even know a lot about it without ever making a purchase decision. The "adoptor" is the aware, knowledgeable purchaser.

It is easy to imagine that there are many opportunities, via the media particularly, for anyone without actual computer experience to become a vicarious adoptor. Computers have become the subject of an ever increasing number of articles and documentaries appearing in newspapers, magazines and television, covering all aspects of the computer industry. The extensiveness of this exposure may offer some partial explanation for the ease with which some older adults, even the very aged, were found to engage in computer interactions (e.g. Weisman, 1983; Condreay, 1984). Some of this initial research seems to suggest attitude problems of older adults toward computers may not prove to be a big issue in this field. It is obvious, however, that more research is required on community-living individuals before definitive statements 
can be made.

\section{Computer Performance}

The cognitive area is one of the most thoroughly researched in all of the aging literature. One of the current trends in this area is to present cognitive tasks to subjects via automated equipment. Performance on standardized cognitive tasks may be affected by computerized presentation of these tasks, instead of the traditional paper-and-pencil versions. However, very few studies have investigated the effect of computerized presentation on cognitive performance. Elwood (1969) found equivalence in performance of college students with manual and computerized testing methods. However, Johnson, et al. (1973) found that computer presentation of materials was detrimental to the performance of some minority groups.

Only two studies (White and Johnson 1975; 1980) used age as a variable in comparisons of computer performance to paper-and-pencil performance. The 1975 study examined the differential effects of a computerized versus a paper-andpencil presentation format of the Wonderlic Personnel Test. Subjects consisted of two groups, 20 subjects in each: a young group (18 to 26 years old) and an older group (60 to 90 years old). The older group evidenced significantly lower scores in the computer condition, relative to both their own pencil-and-paper performance and to the younger 
participants' scores in the computer condition. (There was no significant difference in the paper-and-pencil scores of the two groups).

In the 1980 study, White and Johnson tested two groups of elderly subjects (20 subjects, aged 60 to 80 ) on the computerized version of the Wonderlic test. The experimental group was given one hour of "warm-up" training on the operation of the computer, and also answered fifty non-reactive questions via computer. The control group received the same questions orally. The experimental group averaged significantly higher scores on the Wonderlic Personnel Test than the control group. The conclusion was that with the expenditure of very little effort and time, elderly groups can be tested effectively by computerized methods of presentation.

The two studies by White and Johnson $(1975,1980)$ are examples of the approach suggested by Baltes (1971) for the two stages of research in aging. Stage one type research is concerned with what older people can do and stage two type research is concerned with how to optimize the things they can do. Unfortunately, in both these studies there was a wide range of ages, and a very low number of subjects.

In the rush to automate and keep up with modern trends, not all researchers will be looking at individual differences that may affect performance on computerized tasks. If older subjects are sensitive to the particular testing situation, that fact may go unnoticed, particularly 
in situations where the study may not be in the aging area, but may simply include some older subjects. As researchers have previously demonstrated, and as the studies above also indicate, older subjects may be disproportionately sensitive to the conditions under which learning and testing take place. It is possible that computer learning does represent an age-sensitive area.

\section{Education-C.A.I. (Computer Assisted Instruction)}

Over the last twenty years, the computer has traveled a long distance; all the way from being a clumsy giant of a machine accessible only to specialists in the field, to the situation today where microcomputers are available, affordable and useful to the average person.

Inevitably, educators at all levels have felt the impact of computer technology. To many the microcomputer represents the most efficient instructional tool that has ever been developed (Mierhenry, 1982). At the very least, most educators have recognized the potential for computers to "serve as infinitely patient tutors, scrupulous examiners, and tireless schedulers of instruction" (Kulik, et al., 1980).

The success of computer assisted instruction (C.A.I.), one of several names given to this area, has been researched at the elementary and secondary levels. Vinsonhaler and Bass (1972) and Jamison, et al., (1974) after reviewing the 
literature in this area, concluded that computer instruction is highly effective as a supplement to conventional instruction at the elementary and secondary level in many different areas of study.

At the college level, Kulik, Kulik and Cohen (1980), in a comprehensive article evaluating the success of various C.A.I. programs, concluded that computer instruction was just as effective (as measured by achievement test scores) as conventional methods of instruction. In some cases computer instruction was a modestly better method. students' attitudes toward C.A.I. were generally positive, and the method of instruction (computer versus regular classroom instruction) had no effect on the attitudes of students toward the course material. The most dramatic finding was the benefit of C.A.I. in terms of reducing the amount of time necessary to learn the material. On the average, students receiving computer instruction mastered the course material in about two-thirds of the time required by students receiving conventional classroom instruction.

\section{Adult Education}

In the area of adult education it appears that computer technology has been welcomed with less then open arms. Mierhenry (1982) speculated that the failure of C.A.I. to gain immediate acceptance at this level of instruction is the combined result of the following: reluctance on the 
part of instructors to incorporate the new technology into the classroom, the inappropriateness of the technology to the curricula, and the perceived limitations of the students in terms of education, experience and instructional preference.

According to Mierhenry, many adult educators consider technology to be in opposition to human values. Many of them come from backgrounds in sociology and social work, and they often view C.A.I. as representing a behavioristic or response-oriented approach, rather than a process approach.

Mierhenry reports that adult educators consider interpersonal instruction a requirement for teaching many of the types of courses offered in their programs (e.g., crafts, hobbies, public affairs, personal development, etc.). These educators even suggest that many adults sign up for courses in order to experience personal interaction, rather than to actually acquire information.

Another area of concern to adult educators pertains to the educational experience of adult students. In 1910 only twelve percent of the population had finished high school. However, it was projected that by 1980 forty percent of the population would have high school diplomas (Carnagie Commission on Higher Education, 1973). Adults over the age of sixty today have had less educational experience than younger adults, and also are unlikely to have learned reading or math via computer, as most school age children now do. It is also safe to assume that most people over 
sixty were never introduced to televisions, movies, or typewriters during their school years, as people who are now in their thirties and forties probably were. Therefore, there is likely to be a technological generation gap to be overcome for most adults involved in C.A.I.

The instructional preference of adult students is also an issue to be considered in adult education. Meirhenry reports the results of a study (Commission on NonTraditional studies, 1973) in which most adults indicated a preference for traditional methods of instruction over other methods. Since C.A.I. requires adults to learn material in an unfamiliar way, this may present problems.

Possibly, the problems surrounding the introduction of C.A.I. into adult education may mean computers will never be widely used in this field. However, it would be easy to imagine the potential benefit of gathering research information from all areas of the aging literature in order to design C.A.I. programs potentially effective with adult students. Some of the pertinent findings that might be considered in designing programs would be the well established facts that older people do best in learning environments characterized by relevant materials presented in a supportive context (Ross, 1968), with the opportunity to learn and respond at a self-paced rate (Canestrari, 1963; Kinsbourne and Berryhill, 1972).

One educator, who has taught computer courses to adult students (Stanton, 1985) summarized the special 
considerations to be made in order to effectively teach computers to adult students. He stressed the importance of identifying individuals who may have physical limitations, such as visual or hearing problems, for special assistance. He also emphasized the importance of eliminating extraneous information from the instructions, imparting to the user a sense of being in control, and clarifying the relationship of the computer experience to real-life activities.

There is very little actual research on the effectiveness of computer instruction with older adults. The two studies which examined this issue reported conflicting results.

Rankin (1983) investigated the interaction of anxiety, gender and age within the context of a C.A.I. program at the community college level. Old and young subjects $(n=182)$ (exact ages were not given) were assigned to either a C.A.I. program or to a conventional instruction program. The state Trait Anxiety Inventory was administered before and after treatment. No significant differences were found regarding the effects of anxiety upon performance. However, there was an interaction between age and treatment. All subjects performed more poorly with the C.A.I. program than with the conventional instruction program, but the difference in performance between treatments was most pronounced with the older subjects. Rankin concluded that more study is needed regarding the problems of older students in the use of computers. 
Tamowski (1977) compared performances of students $(n=873)$ ranging in age from 18 to 59 on a multiple choice final exam administered following the completion of a college credit earning C.A.I. course. The older students performed just as well as the younger students, although they did take longer to complete the exam. one important difference between this and the Rankin study is that these subjects chose to register for a C.A.I. course, whereas, Rankin's subjects were assigned to either a conventional instruction program or a C.A.I. program. Perhaps older students who choose a C.A.I. course can be expected to do well. Also, in both cases the older subjects were probably not very old (Rankin's oldest subject was 60, and Tamowski did not specify an age range) and since they were college students they may have been a highly select group of individuals. Once again, the information available from very few studies suggests the need for more research.

One group of researchers, (Jaycox and Hicks, 1976) implemented a community based program which attempted to bring computer learning directly to older adults. The goal of their project was to contact all older adults living in a given community (an unspecified area of Champaign county, Illinois) and to help them to attain a rudimentary level of computer literacy. Factors that differentiate older people, such as physical abilities, educational level, work experience, socio-economic status, ethnic background, etc., were all considered in designing the program. Particular 
emphasis was placed on methods for reaching older people with little formal education. The program was based in community centers and retirement homes in order to provide access to individuals who might otherwise have tended to avoid more "formal" educational settings. Children from local neighborhoods were used as teachers, and careful attention was paid to all aspects of the environment in order to encourage comfort and the willingness to participate. Jaycox and Hicks justify the existence of a computer literacy program by simply stating the value of increasing the number of options available to older people. They emphasize the importance of a communtiy based program for this age group by stating that "the desires to...remain active and to share the wisdom of age with others are not limited to any particular racial, ethnic, or socio-economic group of elders...".

The field of adult education is experiencing tremendous growth nationwide, in terms of both dollars generated for the universities sponsoring such programs and in the number of students enrolled (Livingston, 1986). According to Livinston, adult education centers, which have traditionally tended to offer time-filling courses such as basket-weaving, have now evolved into centers for continuing studies. These programs tend to be associated with the major universities in a given community, and typically offer courses that focus on career development, home improvement, self-improvement and physical fitness, as well as the traditional leisure 
time type of courses.

older students, and certainly the growing number of healthy "young" retirees are among them, contribute to the enrollment in these programs. The fact that course offerings tend to be dictated by a "lassez-faire" vote with your feet system at first glance might seem to be ideal. In this way, the system directly responds to and reflects the interests of the participating students. However, one researcher (Moody, 1976) has suggested that this situation actually reflects a lack of focus in society's approach to educating adults, particularly older adults.

Moody states that older people are viewed as unproductive members of society who do not need to be prepared for careers and, therefore, their participation in the educational process serves only to fill up the abundance of leisure time in their lives. He points out that even the most well-meaning educators, who may make frequent use of nice-sounding phrases such as "life-long learning", do not propose specific curricula designed to meet stated goals for educating older adults. Moody suggests that there is a role for older people to fulfill in order to benefit society. He proposes that those older adults who choose to become involved in the educational process could assist in the process of integrating and compiling areas of knowledge across disciplines, and could also reflect and make judgments on the philosophical questions of the day. His proposal seems to suggest the creation of a new class of 
elite "wise" men and women. Although Moody's suggestion might be called simplistically idealistic, some might even say far removed from reality, it certainly illustrates a point. There is a vast difference between the role of the representative "basket-weaver" at one extreme and the "wise" man or woman at the other. Perhaps this represents the range within which the potential of older adults will be realized in the next few decades. 


\section{PROPOSAL}

The proposed project begins by examining the attitudes of a group of older adults to computers, as measured by the Cybernetics Attitude Scale (Wagman, 1983). Once baseline Computer Attitudes have been determined, an experimental intervention follows, whereby subjects will be assigned to one of three conditions: Group 1) computer Quiz Group - a challenging computer experience involving the "Vocabulary Quiz Game"; Group 2) Paper-and-Pencil Quiz Group - a paperand-pencil version of the same materials as in Group 1; Group 3) Computer Fun Group - a user friendly nonchallenging computer experience involving a computer game entitled "What's in your Lunch?"

Following the intervention, all subjects will again fill out the Wagman (1983) Cybernetics Attitude Scale (CAS), and post-test computer attitudes will be assessed.

\section{Hypotheses}

Hypothesis 1: The attitudes of older adults will be affected by the treatment they experience in this study.

a) Subjects who receive a treatment interaction with the computer will evidence an increase in positive 
attitudes towards computers posttreatment relative to their pretreatment attitude scores.

Subjects who receive a paper-andpencil treatment between the pre- and post-computer attitude measures will show no significant difference in their attitude scores post-treatment. They will function as a control group for computer experience.

b) Subjects who receive a "fun" computer treatment ("What's In Your Lunch?" game) will evidence a greater increase in positive attitudes towards the computer than subjects who receive a challenging computer treatment ("The Vocabulary Quiz Game"). This is proposed based on evidence that older adults may be threatened by challenging situations and helped by supportive situations in a learning context. It is predicted that there will be a significant difference between the treatment groups at Time 2 . Thus, a 
treatment $\mathrm{x}$ time interaction is proposed such that the No computer treatment (control group) will be no different at Time 1 and Time 2. Both of the computer experience treatment groups will demonstrate an increase in positive attitudes at Time 2 compared with Time 1.

It is also predicted that the "fun" computer treatment group will show a greater increase in positive attitudes at Time 2 than will the challenging computer treatment group. Post-hoc tests on the significant treatment $\mathrm{x}$ time interactions will be performed in order to test this hypothesis.

Hypothesis 2: Amongst the older adults in the challenging computer treatment group, those who perform well (i.e., receive high scores and/or complete the task quickly) are more likely to evidence an increase in positive attitudes toward computers post-treatment compared with those who make more 
errors and perform more slowly. Thus, older adults who experience success on a challenging computer task are likely to express positive attitudes following this experience.

older adults who experience difficulty on a challenging computer task (i.e., receive low scores and/or complete the task slowly) are likely to remain unchanged in computer attitudes post-treatment, or possibly even to show a decrease in positive attitudes towards the computer posttreatment.

Hypothesis 3: Older adults who take a vocabulary test on the computer will do more poorly (as measured in number of errors and time to complete the task) compared with older adults who take the same test in paper-and-pencil format. This is hypothesized because older adults have had less experience with computers than they have had with paper-and-pencil tasks, and are, therefore, less familiar with the 
computer method of testing.

Hypothesis 4: Within the older adult group, educational level and/or experience with office machines could be related to attitudes toward computers and performance on them. Years of education and amount of experience on several office machines, including computers, will therefore be assessed. These variables will be correlated with computer attitude measures and with performance on the computer (errors and time). 


\section{METHOD}

\section{subjects}

The subjects consisted of 60 community-living older adults, 13 men and 47 women, ranging in age from 55 to 86 years $(M=70.72)$. All were residents of a middle-income neighborhood in the Kendall area of Miami, Florida. All subjects indicated average to excellent health on self reports and indicated English as their main language. Subjects had an average of 13.63 years of education. Each subject was administered the 35-item Wechsler Adult Intelligence Scale-Revised (WAIS-R) Vocabulary subtest (Wechsler, 1981). The subjects' scaled scores on this subtest range from 7 to $18(\mathrm{M}=11.92)$. The average scaled score on the WAIS-R subtests is 10 .

\section{Materials}

The three self-administered paper-and-pencil instruments and two self-administered computer software programs employed in this study were as follows:

The Cybernetics Attitude scale (Wagman, 1983)

The Cybernetics Attitude scale (CAS) was designed as a means of assessing an individual's attitudes toward 
computer technology. The CAS is comprised of 100 items, 10 items for each of 10 subscales. Each subscale is designed to assess attitudes toward the use of computers in a specific sector or aspect of society. Subjects are instructed to read and respond to each statement on a 7point Likert scale (l=strongly agree with the item; $7=$ strongly disagree with the item). Of the 10 items on each subscale, there were five statements worded to indicate positive attitudes toward computers. Each of these statements had a corresponding converse statement. The complete CAS is arranged to depict the items grouped under each of the 10 subscales (see Appendix A for the items contained in each subscale). When actually administered, however, items are not grouped with respect to subscales (see Apprendix B for protocol including CAS exactly as administered). In scoring the CAS, the scores for the converse items (five of the items on each subscale) were reversed. The scoring system was such that a high total score reflected a negative attitude and a low total score reflected a positive attitude on each subscale, and therefore for the total scale as well.

Wagman (1983) originally administered the CAS to a group of 121 University of Illinois undergraduate students. In order to establish the reliability of Wagman's (1983) results as representative of the attitudes of younger individuals in general, Ansley administered the CAS to a group of 22 college freshmen 
attending Florida International University. The mean total CAS was $404.36(S D=56.80)$ for Wagman's (1983) young sample; the mean total CAS was $409.10(S D=35.57)$ for Ansley's (1985) young sample. (The range of possible scores on the CAS is 100 to 700). The Wagman and Ansley means were not significantly different, $t(141)=.37, p>.05$. Differences between means for the two young adult groups (Wagman's and Ansley's) with regard to the ten CAS subscales revealed a significant difference on only one subscale. The Ansley (1985) young sample had significantly more negative attitudes toward the use of computers on the Finance and Banking subscale than the Wagman (1983) young sample $\underline{t}(141)=2.34, \underline{p}<.02$. See Table 1 for means and standard deviations for the two young adult samples on each CAS subscale. Since the total scores and nine out of ten subscales yielded nonsignificant results for the two young adult samples, the CAS was considered a reliable instrument for young adults. Comparisons of the Ansley (1985) young adults' CAS scores with initial CAS scores of the older adult sample in the present study was therefore considered appropriate.

Machine Experience Survey (Ansley, 1986)

For the present study, a Machine Experience Survey was constructed in order to quantify a person's degree of 
experience with the following seven machines: typewriter, computer, word processor, copy machine, cash register, adding machine and calculator. It was hypothesized that individuals would vary in such experience, and that this would be a potentially important consideration with regard to either performance on, and/or attitudes towards computers. The Machine Experience Survey consisted of 14 statements, two for each of the seven machines. First, the individual indicated the frequency with which each of the machines had been used (response categories ranged from "only once" to "a least once a day"). Next the individual indicated the recency of use (response categories ranged from "using now" to "more than ten years ago"). Responses were assigned a value from one to five, with the lower number representing both a higher frequency of use and more recent experience with the machine. If a machine had never been used, a value of "6" was assigned in both the frequency and recency categories. If a machine had been used very frequently and recently, a value of "l" was assigned in both categories. The addition of the individual frequency and recency scores yielded a Total Experience score for that machine (e.g., a machine that was never used was scored as a "12", and a machine that was used both "now" and "at least once a day" was scored as a "2"). The summation of the individual total experience scores for all seven machines yielded a score representing the total amount of machine experience 
for that individual. Thus, the range of possible values for total machine experience was 14 to 84 . For the present sample actual scores ranged from 21 to 79 , with a mean score of 54.26. (See Appendix B for the protocol, including the Machine Experience Survey).

\section{The "Vocabulary Quiz" Computer software Program}

\section{(Edutek, 1985).}

A software program entitled the "Vocabulary Quiz" was modified by its author (Edutek, 1985) specifically for use in this study. The game format consisted of a twentyquestion multiple-choice vocabulary test, into which vocabulary words and response alternatives could be inserted. The test items (vocabulary words) selected for this study were intended to be challenging for adults with high school educations or the equivalent. Both vocabulary test items and response alternatives were drawn from randomly-selected editions of the Readers Digest, "It Pays to Enrich Your Word Power" feature. only editions published prior to 1983 were used, to avoid coincidental familiarity with the materials. Another feature of the Vocabulary Quiz game was the opportunity to place a bet, in "Play Bucks", on one's ability to correctly respond to each vocabulary word. This feature, as well as the color graphics of the program package, contributed to the "gamelike" nature of the task. Edutek's modification of the original game involved simplifying the procedure for 
placing bets on each word, so that a paper-and-pencil version of the game could more easily be constructed.

In order to play the "Vocabulary Quiz" (computer version) the subject first read a set of instructions as follows:

\section{"THE VOCABULARY QUIZ GAME"}

This game is a short vocabulary quiz in which you can win up to $\$ 1,000$ in Play Bucks by betting on your ability to select the correct meaning for each word.

FIRST you will be shown a word, and asked how much you want to bet on your ability to select the correct meaning of that word. You may bet on any dollar amount from $\$ 10$ to $\$ 50$. Once you have placed your bet, the word will be shown again, but this time with FOUR choices for meanings. You are to select the ONE you think is the correct meaning.

If you are correct, you will win the number of Play Bucks that you bet.

If you are wrong, the number of Play Bucks that you bet will be subtracted from your total winnings.

You will never actually have possession of the Play Bucks, but the computer will keep track of how many play Bucks you have won. The computer is programmed so you will NEVER GO BELOW $\$ 10$ even if you bet the maximum every time and get every answer wrong.

You will not be told whether your answers are right or wrong, or how many Play Bucks you have accumulated, until the end of the game.

The object of the game is to win as many Play Bucks as possible by betting wisely on each of the words presented. It is best to bet on each word regardless of what you think your total accumulated earnings might be up to at that point. Remember even if you do not know the answer you must bet at least $\$ 10$ on each word, but you can bet up to $\$ 50$ on each word.

When you have finished reading this, the person working with you today will give you some practice words, so that you will become familiar with the game before starting. Once you begin the actual game, please do not 
ask any questions unless you do not know how to proceed.

After reading these instructions, the subject was given some practice, and then proceeded to play the "Vocabulary Quiz" on the computer (as described in the Procedure section). Subjects indicated the dollar amount they wished to bet on each word, and then selected answer choices ("A", "B", "C", or "D"), by depressing the appropriate key on a standard alpha-numeric keyboard attached to the computer. Subjects were not given any special training on the keyboard, but prior to playing the game were given a general orientation as to the location of numbers, letters and the return key (which was depressed following each entry). A record was kept of the total amount of time spent on the task, the amount of Play Bucks bet on each item, and the correct and incorrect responses.

As soon as the 20-word game was completed, the monitor screen displayed the total amount of Play Bucks earned. The experimenter then typed a code into the computer which resulted in a visual display on the monitor indicating the correct and incorrect responses. Finally, the correct responses for the words answered incorrectly were verbally communicated to the subject by the experimenter.

The "Vocabulary Quiz" Paper-and-Pencil Version.

A paper-and-pencil version of the "Vocabulary Quiz" was constructed to be as closely equivalent as possible, in both 
content and "game-like" aspects, to the computer version of the game described above. Test items (vocabulary words and choices) were identical to those in the computer version. Word items in the paper-and-pencil version were presented one at a time on single sheets of paper (which were turned over one at a time by the subject). Visual details (letter size and actual arrangement of words and choices on the page) were as nearly identical as possible to the visual presentation on the monitor screen in the computer version. To make the test "game-like" in appearance, self-adhesive pieces of paper covered the answer choices, and the subject was required to peel the papers off before selecting an answer. (The self-adhesive pieces of paper also insured that answers were not accidentally revealed in the event that pages were inadvertently skipped prior to placing a bet.)

In order to play the "Vocabulary Quiz" (paper-andpencil version), the subject first read a set of instructions as follows:

"THE VOCABULARY QUIZ GAME"

This game is a short vocabulary quiz in which you can win up to $\$ 1,000$ in Play Bucks by betting on your ability to select the correct meaning for each word.

FIRST you will be shown a word, and asked how much you want to bet on your ability to select the correct meaning of that word. You may bet on any dollar amount from $\$ 10$ to $\$ 50$. Once you have placed your bet, the word will be shown again, but this time with FOUR choices for meanings. You are to select the ONE you think is the correct meaning. 
If you are correct, you will win the number of Play Bucks that you bet.

If you are wrong, the number of Play Bucks that you bet will be subtracted from your total winnings.

You will never actually have possession of the Play Bucks, but I will keep track of how many Play Bucks you have won. I will make sure that you will NEVER GO BELOW $\$ 10$ even if you bet the maximum every time and get every answer wrong.

You will not be told whether your answers are right or wrong, or how many Play Bucks you have accumulated, until the end of the game.

The object of the game is to win as many Play Bucks as possible by betting wisely on each of the words presented. It is best to bet on each word regardless of what you think your total accumulated earnings might be up to at that point. Remember even if you do not know the answer you must bet at least $\$ 10$ on each word but you can bet up to $\$ 50$ on each word.

When you have finished reading this, the person working with you today will give you some practice words, so that you will become familiar with the game before starting. Once you begin the actual game, please do not ask any questions unless you do not know how to proceed.

After reading these instructions, the subject then proceeded to play the paper-and-pencil version of the "Vocabulary Quiz" (as described in the Procedure section). The dollar amount bet on each word was handwritten on a blank line, and the answer choices for the vocabulary words were indicated by circling the letter ("A", "B", "C", or "D") adjacent to the desired answer. (See Appendix B for the protocol, including the paper-andpencil version of the "Vocabulary Quiz"). A record was kept of the total amount of time spent on the task, the amount of Play Bucks bet on each item and the correct and incorrect responses. 
Following completion of the 20 words, the experimenter totaled the amount of Play Bucks earned, using the same rules as in the computer version, and then informed the subject of the amount of Play Bucks earned. The experimenter next showed the subject a report, similar to the computer report described above, indicating the error words and the correct words. Finally, the correct answers for the words answered incorrectly were verbally communicated to the subject by the experimenter.

\section{The "What's For Lunch" Computer software Program} (Lawrence Hall of Science, 1981).

This software program was selected in order to provide a non-threatening computer interaction experience in a presumably "fun" format. (It should be noted that subjects who played this game actually did appear to enjoy it, as indicated by spontaneous positive comments, smiles and laughter.) The game required the subject to enter, via the computer keyboard, his or her name, sex, age, height, weight and level of physical activity. An approximation of the number of calories that individual should consume in a day was then displayed. Next, the subject entered, from a number-coded list of menu items, the food items he/she consumes for lunch on a typical day. The computer then provided feedback, via a colored graph, indicating the nutritional content of the lunch with regard to the recommended daily allowances of most vitamins, minerals, 
salt, etc. In order to enhance the "fun" aspects of the game, subjects were then asked to design an imaginary lunch that would be very poor in nutritional content. Items were selected and entered by the subject into the computer. A display then appeared with a graphic analysis of the content of this nutritionally poor lunch. The game was then concluded. A record was kept of the total amount of time spent on the task.

\section{Procedures}

Subjects were interviewed individually. During the initial contact each subject was asked to fill out the CAS (Wagman, 1983), and the Machine Experience Survey (Ansley, 1986), as described above. The subject next completed a self-report health form (10-point rating scale), and a demographic information questionnaire (age, sex, years of education). Finally, the Vocabulary section of the WAIS-R was administered in order to provide an index of verbal ability. Upon completion of the above items, an appointment for a second interview was made. This appointment was scheduled to take place no sooner than one week and no later than two weeks from the date of the initial contact. This intervening period allowed enough time between administrations of the CAS to minimize the possibility that subjects would purposefully attempt to give the same answer both times. At the second interview, 
each subject was assigned to one of the three treatment condition described below. An effort was made to match for WAIS-R vocabulary scaled scores when assigning subjects to treatments, and to insure the same male/female ratio across treatments.

\section{Treatment 1: Computer Quiz Group}

A subject assigned to this treatment was first seated in front of a Franklin Ace 1200 computer, and the machine was turned on. Next, the subject read a set of typewritten instructions on how to play the "Vocabulary Quiz" (computer version). To insure that the instructions were understood, a warm-up version of the game (identical to the test version in format, but with only four test words selected from a very easy level of difficulty) was then displayed on the computer screen. The subject was given the same feedback on this warm-up test as would be given following completion of the actual test material. The subject was instructed not to ask questions once the actual test had begun, and he/she then proceeded to play the actual 20-item quiz. Performance measures recorded in this condition included: time to complete the test, the number of errors made, the amount bet on each error word, the amount bet on each correct word, and the total dollar amount earned. Following completion of the "Vocabulary Quiz", the CAS (Post-CAS) was again administered. The 
subject also answered the following typewritten question: "If you were asked to become involved with another project like this one that you have just completed, would you prefer to work with a computer learning center or a traditional paper-and-pencil learning format?" These two tasks were completed immediately following the "Vocabulary Quiz", or no more than one day later.

\section{Treatment 2: Paper-and-pencil Quiz Group}

A subject assigned to this treatment was seated at a small table. Next, the subject read a set of typewritten instructions on how to play the "Vocabulary Quiz" (paperand-pencil version). In order to insure that the instructions were understood, a warm-up version of the game (identical to the test version in format, but with only four test words selected from a very easy level of difficulty) was then played by the subject. The subject was given the same feedback on this warm-up test as would be given following completion of the actual test material. The subject was instructed not to ask questions once the actual test had begun, and he/she then proceeded to play the 20-item quiz. Performance measures recorded in this condition included: time to complete the test, the number of errors made, the amount bet on each error word, the amount bet on each correct word, and the total dollar amount earned. Following completion of the "Vocabulary 
Quiz", the CAS (post-CAS) was again administered, and the subject answered the same typewritten question as in Treatment 1 above: "If you were asked to become involved with another project like this one that you have just completed, would you prefer to work with a computer learning center or a traditional paper-and-pencil learning format?" These two tasks were completed immediately following the "Vocabulary Quiz", or no more than one day later.

\section{Treatment 3: Computer Fun Group}

A subject assigned to this treatment (the "fun" computer interaction experience) was seated in front of a Franklin Ace 1200 computer, and the machine was turned on. The subject was then given verbal instructions on how to play the "What's For Lunch" computer game. Next, the subject was told to begin the game. The only performance measure recorded was the time to complete the game. Following completion of the game, the CAS (Post-CAS) was administered and the subject answered the same question as in Treatments 1 and 2 above: "If you were asked to become involved with another project like this one that you have just completed, would you prefer to work with a computer learning center or a traditional paper-and-pencil learning format?" These two tasks were completed immediately following the "What's for Lunch" game, or no more than one 
day later.

\section{RESULTS}

\section{Pilot study - Young/old Comparison on the CAs Attitude scale}

A series of t-tests were performed on total CAS scores, as well as on subscale CAS scores, for the Ansley (1985) young sample $(n=22)$ and the Ansley (1986) old sample $(n=60)$ pre-treatment scores. There was no significant difference between means on total CAS scores for the young and old samples. The mean was 409.10 $(S D=35.57)$ for Ansley's (1985) young sample; the mean was $399.63(\mathrm{SD}=45.40)$ for Ansley's (1986) old sample. For the subscale t-tests there were significant differences on three subscales: Education $\underline{t}(80)=2.445, \underline{p}<.02$; Values, $\underline{t}(80)=2.4392, \underline{p}<.02$; and Politics $\underline{t}(80)=2.116, \underline{p}<.05$. See Table 1 for means and standard deviations on the CAS subscales and total scores.

\section{Description of older Adult Treatment Groups}

There were three treatment groups in the main study. Twenty older adults were assigned to each of the three treatment groups after they had completed the pretreatment CAS questionaire. A series of analyses of variance revealed no significant differences between means for the three older adult treatment groups on any of the following variables: Age, Health, Years of Education, WAIS Scaled Vocabulary scores, and initial CAS Total (pre- 
treatment) scores. Therefore, these three groups were equivalent on the above variables. See Table 2 for means and standard deviations on each of these variables for each treatment group.

\section{Testing the Hypotheses of the study}

\section{Hypothesis I}

Hypothesis 1 of the study was that the attitudes of older adults towards computers, as measured by the CAS questionaire, would be affected by the treatment they experienced in this study. This hypothesis predicted that the direction of the effect on attitude scores would be dependent on the type of treatment experienced. The two treatment groups that experienced a computer interaction (Computer Quiz Group and Computer Fun Group) were expected to evidence an increase in positive attitudes at Time 2 compared with Time 1. The attitude scores of the subjects in the computer Fun Group were expected to evidence a greater increase than the scores of subjects in the Computer Quiz group, a prediction consistent with research indicating that older adults seem to be threatened by challenging situations as opposed to supportive situations. It was predicted that the attitude scores of subjects in the third treatment group (Paper-and-Pencil Quiz Group), who did not experience a computer intervention, would evidence no change in attitude scores 
at Time 2 compared to Time 1.

In order to test these hypotheses a Treatment (3) $\mathrm{x}$ Time (2) mixed analysis of variance (ANOVA) was performed. The dependent variable was Total CAS attitude score. There was no significant effect for Treatment (Computer Quiz Group, Paper-and-Pencil Quiz Group or Computer Fun Group). There was no significant effect for Time (pretreatment, post-treatment). There was no significant Treatment by Time interaction effect. Since the attitude scores were not affected by the treatments received in this study, Hypothesis 1 was not confirmed.

Treatment (3) x Time (2) mixed analyses of variance were also performed on the ten individual subscales of the CAS as dependent measures. The only significant finding obtained was a main effect for Time on the subscale measuring attitudes towards the use of computers in the area of Math and Statistics, $\underline{F}(1,55)=4.50, \underline{p}<.038$. The pre-treatment mean score was 35.68 , and the post-treatment mean score was 37.17. Attitude towards computer use in the area of Math and Statistics was significantly more negative following treatment than preceding treatment. There was no significant Treatment effect, and there was no significant Treatment $x$ Time interaction for this subscale. 
Hypothesis 2

Hypothesis 2 of the study was that a relationship would be observed between performance (number of errors committed, and/or time to complete the task) and posttreatment CAS attitude scores. Treatment Group 3 (Computer Fun Group) did not involve a task in which the number of errors was recorded. Therefore, this treatment group was only included in the analysis involving time to complete the task. Original plans called for an analysis of the relationship between task performance measures and post-treatment CAS attitude scores. A median split was to be used in order to divide subjects into performance groups based on the number of errors committed (few/many), and the speed of performance (fast/slow). This division was not possible, however, due to the limitation in the range of scores obtained on these variables. Subjects were quite homogeneous and performed well overall. (See Table 3 for means on performance variables by treatment.) However, Pearson correlations were calculated to assess the relationship of performance and attitude scores. There was no significant correlation between total CAS attitude scores (either pre-treatment or post-treatment) and number of errors committed $(\underline{r}=.13, \underline{p}>.05 ; \underline{r}=.11$, p>.05, respectively) for the total sample included in this analysis (Treatment Groups 1 and 2). Likewise, there were no significant correlations for the two treatment groups individually. There was also no significant correlation 
between total CAS attitude scores (either pre-treatment or post-treatment) and time to complete the task, for the total sample $(\underline{r}=.01, \underline{p}>.05 ; \underline{r}=.03, \underline{p}>.05$, respectively), including all three treatment groups. Likewise, there were no significant correlations for the three individual treatment groups.

\section{Hypothesis 3}

Hypothesis 3 of this study was that subjects would perform more poorly on a computerized vocabulary test (Treatment Group 1) than on a paper-and-pencil version of the same test (Treatment Group 2). A one-way analysis of variance (ANOVA) revealed no significant differences between the two groups in the number of errors made, $\underline{F}(1,38)=1.19, \underline{p}>.05$. There was also no significant treatment difference in time to complete the task, $F(1,38)=2.71, \underline{p}>.05$. (Both groups performed well on the test, and there was little variance in scores.)

\section{Analysis of Gambling Features}

Analyses were performed on the gambling features of the Vocabulary Quiz, comparing the performances of subjects from the Computer Quiz and Paper-and-Pencil Quiz groups. Subjects in the computer Fun Group did not receive the Vocabulary Quiz, and this group was therefore not included in the analysis. A one-way ANOVA performed 
on the two treatment groups revealed no significant difference between the groups in the total number of Play Bucks earned on the task $(\underline{F}(1,38)=3.28, \underline{p}<.078)$. The Treatment effect did approach significance, however, with a tendency for subjects in the computer condition to earn more Play Bucks $(M=729.90)$ than subjects in the paper-andpencil condition $(M=562.25)$.

In order to analyze whether the betting strategy of subjects differed for words they subsequently answered correctly versus words they subsequently missed, a Treatment (2) $\mathrm{X}$ Accuracy (correct responses, error responses) mixed ANOVA was performed. The dependent measure was average number of Play Bucks bet on correct responses versus error responses. Accuracy was a within subjects variable since all subjects had both correct and erroneous responses. Ten subjects who earned perfect scores were dropped from the analysis by the BMDP program since they had empty error response cells, and one subject with missing data with respect to those variables was, likewise, dropped from the program. Therefore, 29 subjects remained in the analysis, 14 in Treatment 1 and 15 in Treatment 2. The main Effect for Treatment approached, but did not reach, significance, $\underline{E}(1,27)=3.79, \underline{p}<.06$. Ms $=39.50$ and 30.17 for Treatment 1 (Computer Quiz Group) and Treatment 2 (Paper-and-Pencil Quiz Group), respectively. There was a significant main effect for Accuracy, $\underline{F}(1,27)=11.98, \underline{p}<.002$. There were 
more Play Bucks bet on correct responses ( $M=38.10)$ than on erroneous responses $(M=31.24)$. The Treatment $x$ Accuracy interaction was not significant. Therefore, subjects in both treatment groups bet significantly more on correct responses than error responses.

\section{Subject's Method of Testing Preference}

At the completion of the final session, each subject was asked a question concerning his or her preferred method of testing (i.e., "If you were asked to become involved with another project like this one that you have just completed, would you prefer to work with a computer learning center or a traditional paper-and-pencil learning format?"). Subjects selected one answer to the question from the following two choices: "A computer learning format" or "A paper-and-pencil learning format". The answers were formally scored as follows: the choice of "A computer learning format" was scored as a "Yes" answer; the choice of "A paper-and-pencil format" was scored as a "No" answer. Overall, out of the sixty subjects, 32 answered "Yes" and 28 answered "No". (See Table 4 for subjects' method of testing preference for each treatment.) Analyses were then performed in order to determine whether a significant relationship existed between the answer to the final question and both attitude and performance variables. The question variable, 
therefore, had two levels (yes, no) and was treated for the subsequent analyses of variance as an independent variable, even though it was an organismic variable. A Treatment (3) $x$ Question (2) between groups ANOVA was performed. The dependent measure was Total CAS postattitude score. There was no significant main effect for Treatment (Computer Quiz Group, Paper-and-Pencil Quiz Group, or Computer Fun Group). There was a significant main effect for Question $(\underline{F}(1,54)=7.57, \underline{p}<.008)$. Those who said "Yes" (chose the computer format) had significantly more positive CAS attitude scores than those who said "No". There was no significant interaction effect between Treatment (Computer Quiz Group, Paper-and-Pencil Quiz Group, or Computer Fun Group) and Question (Yes, No). A Treatment (2) by Question (2) ANOVA was performed with errors made as the dependent measure. This time Treatment Group 3 (Computer Fun Group) was not included since errors made were not a measure for this group. There was no significant main effect for Treatment, or for question. The Treatment $x$ Question interaction was also nonsignificant.

\section{Analysis of Machine Experience Survey}

Hypothesis 4

Hypothesis 4 of the study was that educational level and/or experience with office machines could be related to 
attitudes toward computers and performance on them. In order to test this hypothesis correlations were performed as below.

All subjects completed a Machine Experience Survey, which was constructed in order to quantify a person's degree of experience with the following seven machines: Typewriter, Computer, Word Processor, Copy Machine, Cash Register, Adding Machine and Calculator. The survey consisted of 14 statements, two for each of the seven machines. For each machine, subjects indicated both the frequency and the recency with which the machine had been used. The addition of the individual frequency and recency scores yielded a Total Experience score for that machine. The summation of the individual Total Experience scores for all seven machines yielded a Total Machine Experience score (representing the total amount of machine experience for that subject). Low scores indicated more experience and high scores indicated less experience. See Table 5 for the range of scores for frequency and recency of use for each machine. Pearson Correlations were calculated between Total Machine Experience scores, Experience scores for each machine, and several other measures. One area examined was the relationship between machine experience and number of years of education. (Low scores on machine experience indicate more experience with that machine.) Total Machine Experience was not significantly correlated with number of years of education 
$(\underline{r}=-.072 \underline{p}>.05)$. However, there were significant correlations between years of education and machine experience with specific machines. Less cash register experience went with a high level of education $(\underline{r}=.325$, $\underline{\mathrm{p}}$.006); less word processor and copy machine experience went with a high level of education ( $\underline{r}=.21, \underline{p}<.055$; $\underline{r}=.32, \underline{p}<.007$, respectively). Computer experience was not signficantly correlated with education. Also, for Treatment Groups 1 and 2 (Computer Quiz Group and Paperand-Pencil Quiz Group) computer experience was not significantly correlated with either the number of errors made $(\underline{r}=.143, \underline{p}>.05)$, or with time to complete the task $(\underline{r}=.190, \underline{p}>.05)$. Computer experience was significantly correlated with CAS attitude scores (both pre and post)), $\underline{r}=.267, \underline{p}<.019, \underline{r}=.330, \underline{p}<.005$, respectively. Negative attitudes toward computers went with less computer experience. 
DISCUSSION

The results of this study were, for the most part, not supportive of the hypotheses. However, the results do present a consistent, although unexpected, pattern concerning the attitudes and performances of older adults with respect to computers.

\section{Attitudes Toward Computers}

The finding of no significant difference in the initial attitudes of old and the initial attitudes of the young subjects towards computers, as measured by the CAS, was somewhat surprising. (Although attitude scores differed on three of the ten subscales, there was no significant difference in the total CAS scores for the two groups.) Considering the thoroughness with which the CAS instrument examines attitudes (100 items are included), and the evidence of scale reliability [there were no significant differences between the CAS scores of Wagman's (1983) young group and Ansley's (1985) young group], this finding supports the conclusion that well-educated, middle-class older adults do not express significantly different attitudes toward computers compared with younger adults selected from a middle-class college student body. A generalization cannot be made from this study concerning the attitudes of a broader segment of older adults toward 
computers. However, the findings suggest that there is not a predominantly negative attitude toward computers among older adults, and, therefore, attitude may not prove to be a barrier in introducing computer technology to individuals in this age group. At the very least, no assumption should be made concerning attitudes in this area.

Total attitude scores on the CAS were unaffected by treatment conditions (there was a finding of only one significant subscale difference out of ten). Therefore, the short-term intervention (averaging a total time of 7 minutes, 37 seconds spent with the computer per subject), involving testing with materials that most subjects found to be easy, was not powerful enough to significantly influence CAS attitude scores. Since subjects were favorably disposed to computers initially (at least as favorably disposed as their younger counterparts), and also revealed little variation in their CAS attitude scores, it is not surprising that the interventions had no significant effect on performance (subjects did equally well on the test material in both conditions). Likewise, it was also not surprising that attitude scores remained unaffected by the intervention.

For future research, perhaps selecting subjects more representative of the older adult population, who display a wider range of initial CAS attitude scores, and designing challenging interventions (e.g., tests involving 
fluid abilities and tests which employ time limits) would be more likely to result in significant performance and attitude effects.

\section{Attitudes and Performance}

The finding of no significant correlation between CAS attitude scores and the performance measures (i.e., the number of errors committed or the time to complete the task) suggests that an individual's attitude toward computers in general is not related to how well he or she performs with a computer. However, for the present study it should be noted that the performances of subjects were high. Therefore, obtaining a significant relationship between performance measures and attitude measures was unlikely. More challenging tasks might result in findings different from those obtained here.

The hypothesis that older adults would perform more poorly on the test materials in the computer condition than in the paper-and-pencil condition was not substantiated. There were no significant differences in number of errors committed, time to complete the task, amount of money earned, or the amount bet on each word for the two conditions (Computer Quiz Group and Paper-andPencil Quiz Group). Thus, the effect of mode of testing on performance was negligible in this study. This result suggests that older adults can easily handle computer 
interactions involving verbal materials that are not difficult, that are presented in a relatively unambiguous format, and that are introduced in a non-threatening context (with simple training provided and help available if necessary).

\section{Betting Behavior}

Subjects showed a borderline tendency to bet more and earn more PlayBucks in the computer condition than in the paper-and-pencil condition. Likewise, since few errors were committed overall by subjects, this finding also indicates subjects showed a borderline tendency to bet more Play Bucks in the computer condition. Previous research (Ross, 1968; Wallach and Kogan 1961) has suggested that older adults are more likely than their younger counterparts to exhibit cautiousness under varying conditions, including challenging situations. The tendency for subjects in this study to bet (risk) more Play Bucks in the Computer Quiz Group condition (which for most involved a novel experience) as opposed to the paperand-pencil condition lends little support for such cautiousness. Of course, it is possible that the aura of the "game" aspects of this intervention lessened any tendency for the older adults in the Computer Quiz Group to display cautiousness. However, the results obtained in this study are more in line with the findings of okun and 
Elias (1977), who reported that under conditions in which risk-taking behavior is rewarded, older subjects are not any more cautious than younger subjects. It would be interesting to assess the effect of introducing real money into the betting situation. Future work is needed for examining cautiousness and risk-taking behaviors in the context of computer interactions.

An additional finding was that subjects bet more Play Bucks on words that they subsequently answered correctly than on error words. This was true regardless of treatment condition, and indicates that the subjects used an effective betting strategy. This can be interpreted as an indication that older adults evidence appropriate metacognition. The subjects' ability to formulate an effective betting strategy based on an awareness of their own fund of vocabulary knowledge was equal in computer and Paper-and-Pencil testing conditions. Since the test words were all set at the same level of difficulty, it was, therefore, a particularly robust demonstration of the subject's ability to distinguish between the words they knew and those that they were less sure of.

It has become commonplace during recent years for there to be more opportunities, and even requirements, for some degree of computer use. Automated banking is becoming the rule in most areas, voting in elections is becoming increasingly an automated process, and even being able to comprehend the output from computers, such as 
reading a phone bill or bank statement, involves a minimal understanding of how computers function. The simple, short-term computer interactions required of the subjects who participated in this study (which involved following a sequence of instructions, selecting choices from a group of statements, and manipulating dollar amounts in the form of Play Bucks) were quite similar to computer interactions likely to be encountered by the average adult in everyday life. In general, the older adults in this study were not negatively affected by computer as opposed to paper-andpencil format of the interaction. It seems likely, based on this outcome, that older adults similar to this subject sample would be capable of adapting to advances in computer technology in the above-mentioned "real world" tasks.

\section{Subjects Method of Test Preference}

Slightly more than half the subjects in this study (32 out of 60) selected a computer learning format over a paper-and-pencil format as a preferred method of future testing (the Question variable). The finding of no effect for Treatment for this variable indicates that the interventions presented in this study, two involving computer interactions and one paper-and-pencil, had no significant effect on the subjects' subsequently stated format preference. This indicates that attitudes in this 
area are quite stable. The fact that half the subjects chose the computer format was surprising. As previously reported (Commission on Non-Traditional Study, 1973) older individuals prefer familiar, rather than novel, methods of instruction. The findings here offer encouragement to those who seek to use computer-based instruction and testing with older individuals.

The finding that computer attitude scores (posttreatment) were significantly higher for subjects who stated a subsequent preference for a computer format, but that performance measures were not significantly related to format preference, suggests that attitudes may be a more important aspect of testing preference than experience. However, since subjects generally performed at a high level, this finding needs more thorough investigation.

\section{Machine Experience}

Computer experience was not significantly correlated with performance on the Vocabulary Quiz for either the Computer Quiz Group or the Paper-and-Pencil Quiz Group. Since prior computer experience was not significantly related to how well the subject performed, this outcome reflects the ease with which the computer was handled by the subjects in this study. It is possible that the task requirements in this study were not sufficiently difficult 
to produce any distinction between those with or without computer experience. Perhaps the use of a more difficult computer task in a similar study would provide a context within which correlations between performance and experience would be evidenced.

Attitudes toward computers were significantly correlated with computer experience, such that positive attitudes went with more computer experience. It was, therefore, interesting that the experience provided in this study had no significant effect on attitude scores. of course, the pre-treatment attitudes of the older adults' in this study were not negative, so this may account for this finding. It remains to be seen how much computer experience and what kind of experience would produce significant effects on attitudes in this area.

In summary, the findings of this study suggest that older adults can handle simple computer interactions quite well, and that neither attitude, nor previous experience should affect performance. Of course, as noted earlier, the subjects in this study were all middle class, educated, healthy older adults. These findings may not be generalizable to a broader segment of the older adult population. 
Table 1--Means and Standard Deviations for Three Sample Groups on the Ten subscales and Total scores Comprising the Computer Attitude Survey (CAS)

SAMPLE

Subscale

Young a

(Wagman, 1981)
Young $b$

(Ansley, 1985)
Old $C$

(Ansley, 1986)
1. Society

2. Values

3. Cognition

4. Counseling

5. Education

6. Medicine

7. Politics

8. Criminal

Justice

9. Finance and

Banking

10. Math and

statistics
$\underline{\mathrm{SD}} \frac{35.60}{9.18}$

M 44.05

SD 6.80

M 42.72

SD 8.78

M 51.84

SD 8.74

M 47.05

SD 9.23

M 45.73

SD 7.20

M 34.36

SD 7.35

M 32.66

SD 7.32

M $35.86 \mathrm{~g}$

SD 7.56

M 34.31

SD 7.83

$$
\frac{37.09}{7.86}
$$

$\frac{35.30}{7.15}$

$43.50 \mathrm{~d}$

5.09

$\frac{40.62 d}{4.61}$

41.40

8.19

38.96

8.12

49.59

11.11

$\underline{48.40}$

7.04

$48.52 \mathrm{e}$

10.7

$\frac{43.83 e}{6.30}$

6.30

$\underline{45.95}$

$\underline{46.90}$

7.72

7.11

$\frac{34.04 f}{6.19}$

$\frac{37.42 f}{6.49}$

32.90

$\underline{6.53}$

$\underline{32.83}$

6.46

$\frac{39.77 \mathrm{~g}}{4.78}$

$\underline{39.68}$

$\underline{4.78}$

6.39

36.04

$\underline{35.68}$

5.89

7.50

Total CAS Score

M 404.36

SD 56.80

$\frac{409.10}{35.57}$

$\underline{399.63}$

45.40

NOTE: T-tests were performed on the CAS subscales and the total score for the Wagman (1981) young sample and Ansley (1985) young sample, and also for the Ansley (1985) and the Ansley (1986) old sample. Means with the same subscripts differ significantly at $\underline{p}<.05$. All other comparison are non-significant.

$a_{\underline{n}}=121$.

$\mathrm{b} \underline{\underline{n}}=22$.

$\underline{\underline{n}}=60$. 
Table 2--Mean Scores for Demographic Variables for Each Treatment Group

Treatment group a

\begin{tabular}{|c|c|c|}
\hline $\begin{array}{l}\text { Computer Quiz } \\
\text { Group (1) }\end{array}$ & $\begin{array}{l}\text { Paper-and-Pencil } \\
\text { Group (2) }\end{array}$ & $\begin{array}{l}\text { Computer Fun } \\
\text { Group (3) }\end{array}$ \\
\hline
\end{tabular}

\begin{tabular}{|c|c|c|}
\hline $\begin{array}{l}\text { Health } \\
0=\text { poor } \\
10=\text { excellent }\end{array}$ & 7.70 & 7.00 \\
\hline
\end{tabular}

\begin{tabular}{lllll}
\hline Age & 70.00 & 71.45 & 70.70 & 70.72 \\
(in years) & & & &
\end{tabular}

Education 13.50

13.45

13.95

13.63

WAIS

12.35

11.60

11.80

11.92

Vocabulary

(scaled score)
a $\underline{n}=20$ for each group.
b $\underline{n}=60$ for total sample. 
Table 3--Mean Performance scores for Each Treatment

Treatment group a

$\begin{array}{lllll}\text { Computer Quiz } & \text { Paper-and-Pencil } & \text { Computer Fun } & \text { Total } \\ \text { Group (1) } & \text { Group (2) } & \text { Group } & \text { (3) } & \text { Sample } \\ \text { Meanb }\end{array}$

Average Time

to complete

$6.62 \mathrm{~min} . \quad 7.98 \mathrm{~min}$.

$8.26 \mathrm{~min}$.

7.37

task

NA

2.72

Average Errors

made (out of 2.25 errors 3.20 errors

min.

20 items)

$a_{\underline{n}}=20$ for each group.

$\mathrm{b}_{\underline{n}}=60$ for total sample. 
Table 4--Subjects' Method of Testing Preference for Each Treatment

Treatment group

Method of

Testing

Preference $\begin{array}{ll}\text { Computer } & \text { Paper-and- } \\ \text { Quiz Group } & \text { Pencil Group }\end{array}$

(\# of sub- (2) (\# of

jects out subjects

of 20) out of 20)
Computer Total

Fun Group (\# subjects (3) (\# of (out of 60) subjects out of 20)

Computer

"Yes"

11

7

10

32

Paper-andPencil

"No" 
Table 5--Description of Machine Experience for the study Sample

Mean Experience \# of subjects who
total sample a never used the machine
$(\mathrm{N}=60)$
(out of total sample
$\mathrm{N}=60)$

\# of subjects who use machine "now"/"everyday" (out of total sample $\mathrm{N}=60$ )

Typewriter

6.37

16

11

Computer

10.12

45

3

Word Processor $\quad 10.80$

52

3

Copy Machine

6.15

15

8

Cash Register

8.17

22

0

Adding Machine

7.05

16

4

Calculator

5.62

10

8

TOTAL MACHINE EXPERIENCE: b 54.26

apossible range of values for this variable was "2" for "using now/"at least once a day" to "12" for "never used".

bpossible range of values for this variable was "14" for all seven machines scored as "using now"/"at least once a day" to "84" for all seven machines scored as "never used." 


\section{LIST OF APPENDICES}

A. The Cybernetics Attitude Scale (100 items)

B. General Backgound Information - a demographic information form.

C. Health - health information form.

D. Machine Experience Survey - a survey of experience with office machines.

E. Questionnaire - the Cybernetics Attitude Survey (CAS), as administered to subjects.

F. Vocabulary Quiz Game - Summary Sheet - the form used to record Subjects' performance.

G. "The Vocabulary Quiz Game - Warm-up" - the warm-up version of the Vocabulary Quiz, exactly as administered to each subject in the paper-and-pencil condition.

Note: The actual test words (as on the Vocabulary Quiz Game - Summary sheet above) were administered to subjects using the exact format as in the "warm-up" version. 
ferl that a computer liculith survey wisuth the meste ystematic than a heallh survey taken by a doctur. (49) think that petsonal answers to a compuice health uncy would be acpt in sli.itcr ainfidence than inewers in a doctor's survey. (14) r. medical diafnosis, I be. In.vi. Ihal cxiniputers ife laver and more arrurale than a dectiot. (4)

I think it is valuable in have cumputers to foretast the ouliegmes of elections. (25)

When computers rejait the uut conies ai electin. Ins, the ocmectatic process is made nore clfective. (74)

I have mote confidince when voter are counted by a rompuler than when they ase counted by an eiection offical. (34)

When a compule kecps recend as contrihuterns lis metiticians. electinne are made fauter. (\$2)

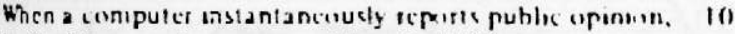
both citizens and fovernment bencfil. (50)

Pulines

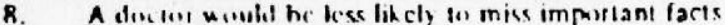
abriu! iny heallt than wiruth a computer. (96)

9. I could $\ldots$ in be sure who would sec my answers to a computer health suncy. (46)

111. A compusel con nevet replase the experience and intuinin of a piend doctor. (62)

6. Lurecustinf the culcume ol electikins by computers inieffetes with the clection process. (27)

7. When computers icpult the outcouncs of electums instanianeriusly, the pessitility of naming the wisns person arwinncr incteases (2)

8. An clictinin official would he less likely to make a inisiake in countint hallols than a computer would. (il)

9. Kecping a computer accounting of political crintrithutems duce mil deter illicgal cantrithuteuns. (75)

Remurting puthlic upiniun hy ormputer may interlers with ihe functruning of the furcernment. (54)

\section{Criminal Jusice Sysicm}

I think it is desiratic lo have informalein aterut riminals sored in computers. (12)

The usc of $\infty$ mouters in kecping crime statestics benefils the pubic (15)

Ifeel safe: knowirf the poliec can use the compuler's high speed and extensive memory to help in the apprehensinn of criminals. (51)

I do mot think my ficedom is roduced by the visesfreas use of computers in the justice sy $5 \mathrm{~cm}$. (64) There is really no way in which intwocent citiucns can be harmed by the ase use of computers in the justive sy stem. (76)

6. Idin't think compulers have a place in the justice sysiem. (8S)

7. The crime statisticskept on computers are 100 misicadinf in he much good. (36)

8. The usc of the speed and memory of computers to helf apprehend criminals does not realy help to deter crime (90)

9. The widesprad use of computers in the justice system violates mi rachis. (70)

10. It is 100 easy to makc a mistake and harm an innocent person when compulers are uxed in the justice sysiem. (67)

Finance and Bankine

As compared with poople, computers are more accurate in kecpine iccerds of personal financial tranuctions. (57)

Gredit and other financial tranections al: ?ariet when donc through a computer than wiren dume thruugh people. (32)

Peromal credit information can be kcpt just as privale and confidentiai on computcrs as through any other medium. (24)

Ido mot think that persenal crodit information stured in computers will inierfere ith my his to privacy. (83) The danger of theft of peisonal funds is mot increased by the ux of compuices in banking and aodit operations. (92)

The computer's ifhinieg swifl cahulatimg s.ulity and nearly infinite memoly ale entively desirable. (19) li would be desiable to $\mathrm{kam}$ ratisics from a computer becaus mor statistics are calculaled on compulers (30)

It is betlet fo otre trath o: statistics problems by compules thas by hand. (73)

I would have more trust in sta : istica proixsuod by a computer than by hand. (93) I would fecl moxs comiortable doing miath or statislics by compules than by hand. (79)
6. Computers can never match the accuracy of trained prople in kreping iccouds of tinancial transations. (66)

7. There are more important thiss to considet about financial transactions than the speed a compuiet can give (!s)

8. The use of compulers to record personal credit information increases the possibility of othe! people pettisc hold of perional information about me. (29)

9. My richtsare morc easily viobied hen computers sore personal credit information about me. (33)

10. Theft of petsonnal fund has gleatly incicased since compuiers - ere introducod into credit and banking upraikins (7)

Mathematica and Statistics

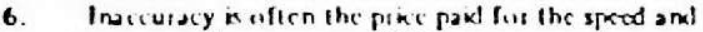
memory of a compulct. (48)

7. Statistics should be karned and undersood before a compute: is unod for their cakulation. (58)

8. Solving statistics or math probiems by hand is ofien beiler than usine the compuler to sotre these probicms. (84)

9. I would use more caution in usine computer-calculated satistica than hand-alculated as atistics. (43)

10. All in $2 \mathrm{ll}, 1$ wouk prel. 10 do math or sististic myelf than use a compulet. (2R) 


\section{GENERAL BACKGROUND INFORMATION}

Hrections: These questions are about your general background. Mark your answers in the answer sheet.

\section{AGE}

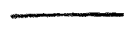

2. SEX



3. COUNTRY OF BIRTH

4. WHAT IS YOUR MAIN LANGLAGE?

1. USA 2. Other

5. IF NOT USA, BOW LONG HAVE YOU LIVED IN USA?

1. Less than 1 year 2. 1 to 2 years 3 . 2-5 years

4. 5-10 years 5. 10 or more years

6. ETHNIC BACKGROUND

1. Anglo American

2. Black Aserican

3. Spanish American

4. Other
7. YEARS OF SCHOOL COMPLETED

1. Professional (M.A.; M.S.; M.E.; M.D.; Ph.D

2. Four-Years college student (A.B.; B.S.; B.l

3. 1-3 years college

4. High school graduate

5. 11 years of school or less

3. WHAT IS YOUR OAN RELIGIOUS AFFILIATION OR PREFERERCE?

1. Catholic

2. Jewish

3. Protestant

4. None

5. Other

YOUR PRIMAPY OCCUPATION (IF RETIRED, FORNER OCCUPATION)

IF MARRIED OR WIDOHED, SPOUSES OCCUPATION (DURING HIS/HER HORKING YEARS) 
10 INDICATES EXCELLENT HEAITH. 5 INDICATES AVERAGE BEAITH. O INDICATES POOR HEAITH. CIRCLE A NUMBER SHOWING HOW YOU RATE YOURSELF IN HEAITH. WHAT DO YOU THINK YOUR PRESETT HEALTH IS? CIRCIE A NUNBER TO TELI ME.

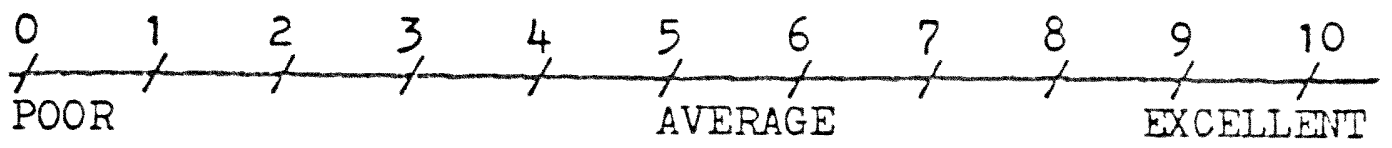

DO YOU HAVE PROBLEMS WITH ANY OF THE FOLIOWING?

(Answer "YES" or "No" to each. Answer "NO" if the problem has been corrected to within normal limits by glasses, hearing aide, etc.)

SEEING -

YES NO IFYES, BRIEFLY EXPLAIN

EEABING -

YES TO . IF YES, BRIEFLY EXPLAIN

WRTTING -

TES NO IFYES, BRIEFLY EXPIAIN

READING - 
Please read the name of each machine below, and put a check mark to indicate if you have ever used the machine. Also, indicate with a check mark how recently you uscd the machine, and how frequently.

MACHINE NAME

(Check one)

'EWRITER
2. HOW RECENTLY USED? (check one)
3. HOW FREOUENTILY USED (Check one)
ONLY ONCE

SE!EKNL TIMES

UNCE A NUNOIi

ONCE is W:O:

Az ZLSZ $\because \mathrm{CZ}$

f. $=A Y$

BETWEE: FIVE AND TEN YEARS

AGO

MORE THAN TEN YEARS AGO

IMPIJTER _ used



\section{OCESSOP.}

_used

n_. never used
USING NOW

NOT NOW, BUT WITHIN THE LAST

YEAK

BETWEEN TWO AND FIVE YEARS

AGO

BETRLEN FIVE AND TEN YEAKS

$\triangle G O$

MOKE THAN TEN YEARS AGO

USING NOW

NOT NOW, BLI WITHIN THE LAST

YEAR

BETWEEN TWO AND FIVE. YEAKS

$\triangle \mathrm{CO}$

BEIWEIN FIVE ANI TEN YEARS

$A($,

MORL T7MAN TEN YLARS ACO
USING NOW

NOT NOW, BUT WITHIN THE LAST

YI:AR

BF.TWEEN TWO ANI) FIVE YFARS

A(i)

BETWEEN FIVE ANI) TEN YEARS
ONLY ONCE

SEVFKAI. TIMI.

ONCE A MOA:TH:

ONCF A WEFK

A IE:O OIZE

A. IA:
ONLY (NACE

SEVERAL TINES

ONCE A MUNTIi

ONCE A WEEK

AT LEESE O:CE

A. DAY
ORLY UNCF

SEVthA! TI I!:

ONCE A MONTH

ONCE. A L'EEK

AT IEAS ONE

A D. I 
MAl.uInt. NinMt: (Check one)

SH REGISTER -

... never used

$=$

ING, MACH:INE

ised

never used
2. H(HW kLC:NTLLY USLII:

USING, NOW

NOT NOW, BUT WITHIS THE. I.AST

Y FAR

BE.'IWEEN TWO ANI) FIVE YEAK:

ACO _.

BEIWEEN FIVE NII TEN YHAKS

A(;)

MORE THAN TEN YEAHS AGU

USIN: $\mathrm{HOH}^{-}$

NOT NOW, BUT WITHIS THE LAST

YEAR

BETWEEN TWO AND FIVE. YEAKS

ACO

BETWEEN FIVE AND TEN YEARS

AGO

MOKE THAN TEN YEAPS AGO

CALCULATOR

$=$

used

never used
USING NOW'

NOT NOW, BUT WITHIN THE LAST

YEAR

BETWIEEN TWO NND FIVE YFAKS

$A(j)$

BEIWEE FIVE AW IE: YIAS

$\mathrm{ACU}$

MORF TIAY TEX YEA:S A(;)

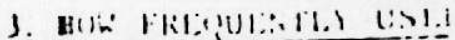
(cherk ons)

UNLY OACL _.

SFVFRAI TISIFS

(INCF A MU):

ONCF i WIEK

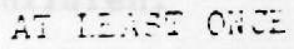

$\therefore \because \because$

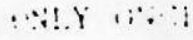

SHVIRiL I!:1E:

(1):3 $\therefore$ \&

UNCE $i$ WFti

$\therefore \quad L \therefore: \cdots U$



(ISL) OXIE _SFVEFAL IIMES

oN(F A : $: M T H$

INCF A WFEL -..

$\therefore=$ ZE

A $24:$ 


\section{Questionnaire}

Directions: This questionnaire contains a serles of statements. Following each statemen are flue choices. The choices represent a range of opinions from very strongly agree to very stro gly disagree. You will clrcle the one cholce that comes closest to your opinio about each individual statement. Remember, there are no right or wrong answers. Your opinion is most 1aportant, so please answer as you feel.

1. It is a good 1dea to use computers to teach concepts to grade school children.

\begin{tabular}{|c|c|c|c|c|c|c|}
\hline 1 & $1^{2}$ & $1^{3}$ & $1^{4}$ & $1^{5}$ & $1^{6}$ & $f^{7}$ \\
\hline$\sqrt{\text { ery }}$ & Strongly & Agree & Neutral & Disagree & Strongly & ery \\
\hline $\begin{array}{c}\text { Strongly } \\
\text { Agree }\end{array}$ & Agree & & & & Disagree & $\begin{array}{l}\text { Strorgly } \\
\text { Disagree }\end{array}$ \\
\hline
\end{tabular}

2. When computers report the outcomes of elections 1nstantaneously, the possiblity of naming the wrong person as winner increases.

\begin{tabular}{|c|c|c|c|c|c|c|}
\hline $1^{1}$ & $j^{2}$ & $j^{3}$ & $1^{4}$ & $i^{5}$ & $1^{6}$ & $1^{7}$ \\
\hline very & Strongly & Agree & Neutral & Disagree & Strongly & Very \\
\hline $\begin{array}{c}\text { Strongly } \\
\text { Agree }\end{array}$ & Agree & & & & Disagree & $\begin{array}{l}\text { Strongly } \\
\text { Disagree }\end{array}$ \\
\hline
\end{tabular}

3. I would be more comfortable talking to a doctor than to a computer about wy health problems.

\begin{tabular}{|c|c|c|c|c|c|c|}
\hline $1^{1}$ & $\prime^{2}$ & $1^{3}$ & $1^{4}$ &,$^{5}$ & $1^{6}$ & $1^{7}$ \\
\hline very & Strongly & Agree & Neutral & DIsagree & Strongiy & \\
\hline $\begin{array}{l}\text { Strongly } \\
\text { Agree }\end{array}$ & Agree & & & & Disagree & $\begin{array}{l}\text { Strongly } \\
\text { Disagree }\end{array}$ \\
\hline
\end{tabular}

4. In medical diagnos1s, I believe that computers are faster and more accurate than a doctor.

\begin{tabular}{|c|c|c|c|c|c|c|}
\hline 1 & $f^{2}$ & $1^{3}$ & $1^{4}$ & $1^{5}$ & $1^{6}$ & $1^{7}$ \\
\hline very & Strongly & Egree & Neutral & Disagree & Strongly & Very \\
\hline $\begin{array}{l}\text { Strongly } \\
\text { Agree }\end{array}$ & Agree & & & & Disagree & $\begin{array}{l}\text { Strongly } \\
\text { Disagree }\end{array}$ \\
\hline
\end{tabular}


5. If a person does all of his math problems on a computer, he will forget how to do these problems by hand.

\begin{tabular}{|c|c|c|c|c|c|c|}
\hline $1^{1}$ & $1^{2}$ & $1^{3}$ & $1^{4}$ & $1^{5}$ & 6 & 1 \\
\hline$\sqrt{\text { ery }}$ & Strongly & Agree & Neutral & Disagree & Strongly & Very \\
\hline $\begin{array}{c}\text { Strongly } \\
\text { Agree }\end{array}$ & Agree & & & & Disagree & $\begin{array}{l}\text { Strongly } \\
\text { Disagree }\end{array}$ \\
\hline
\end{tabular}

6. I think a computer could have more information to help me solve my problems than a counselor could have.

$\begin{array}{ccccccc}1^{1} & 1^{3} & 1^{3} & 1^{4} & 1^{5} & 1^{6} & 1^{7} \\ \begin{array}{c}\text { Serrygly } \\ \text { Agree }\end{array} & \begin{array}{c}\text { Strongly } \\ \text { Agree }\end{array} & \text { Agree } & \text { Neutral } & \text { Disagree } & \text { Strongly } & \text { Very } \\ \text { Disagree } & \text { Strongly } \\ \text { Disagree }\end{array}$

7. Theft of personal funds has greatly increased since computers were introduced into credit and banking operations.

\begin{tabular}{|c|c|c|c|c|c|c|}
\hline 1 & $1^{2}$ & 3 & $1^{4}$ & $1^{5}$ & 6 & $i^{7}$ \\
\hline very & Strongly & Agree & NeutraI & Disagree & Strongly & Very \\
\hline $\begin{array}{c}\text { Strongly } \\
\text { Agree }\end{array}$ & Agree & & & & Disagree & $\begin{array}{l}\text { Strongly } \\
\text { Disagree }\end{array}$ \\
\hline
\end{tabular}

8. I would like working with a computer because it doesn't play favorites as a teacher might.
$\frac{1}{\sqrt{\text { very }}}$
Agree
$1^{4}$
Agree

$\begin{array}{lll}1^{5} & /^{6} & /^{7} \\ \text { Disagree } & \text { Strongly } & \text { Very } \\ \text { Disagree } & \text { Strongly } \\ & & \text { Disagree }\end{array}$

9. A counselor could help me more than a computer could with my personal problems becaus a counselor would have more experfence with my type of problem.

$\begin{array}{ccccccc}1 & 1^{2} & 1^{3} & 1^{4} & 1^{5} & 1^{6} & \left.\right|^{7} \\ \begin{array}{c}\text { Very } \\ \text { trongly } \\ \text { Agree }\end{array} & \begin{array}{c}\text { Strongly } \\ \text { Agree }\end{array} & \text { Agree } & \text { Neutral } & \text { Disagree } & \text { Strongly } & \text { Very } \\ \text { Disagree } & \text { Stronily } \\ \text { Disagree }\end{array}$


10. I could be more frank and open when answering a computer's health questions than questions from a doctor.

\begin{tabular}{|c|c|c|c|c|c|c|}
\hline 1 & $1^{2}$ & $1^{3}$ & $1^{4}$ & $1^{5}$ & $1^{6}$ & $1^{7}$ \\
\hline very & Strongly & Agree & Neutral & Disagree & Strongly & Very \\
\hline $\begin{array}{c}\text { Strongly } \\
\text { Agree }\end{array}$ & Agree & & & & Disagree & $\begin{array}{l}\text { Strongly } \\
\text { Disagree }\end{array}$ \\
\hline
\end{tabular}

11. An election official would be less likely to make a mistake in counting ballots than a computer would.

\begin{tabular}{|c|c|c|c|c|c|c|}
\hline 1 & $i^{2}$ & $1^{3}$ & $1^{4}$ &,$^{5}$ & 6 & $1^{7}$ \\
\hline$\sqrt{\text { ery }}$ & Strongly & Agree & Teutral & Disagree & $\frac{1}{\text { SErongly }}$ & $\frac{1}{\text { Very }}$ \\
\hline $\begin{array}{l}\text { Strongly } \\
\text { Agree }\end{array}$ & Agree & & & & Disagree & Strongly \\
\hline
\end{tabular}

12. I think it is desirable to have information about criminals stored in computers.

$\begin{array}{ccccccc}1 & 1^{2} & 1^{3} & 1^{4} & 1^{5} & 1^{6} & 1^{7} \\ \begin{array}{c}\text { Very } \\ \begin{array}{c}\text { trongly } \\ \text { Agree }\end{array}\end{array} & \begin{array}{c}\text { Strongly } \\ \text { Agree }\end{array} & \text { Agree } & \text { Neutral } & \text { Disagree } & \text { Strongly } & \text { Very } \\ \text { Disagree } & \text { Strongly } \\ \text { Disagree }\end{array}$

13. A computer cannot replace man's flexibility in solving problems.

\begin{tabular}{|c|c|c|c|c|c|c|}
\hline 1 & 2 & $1^{3}$ & $1^{4}$ & $j^{5}$ & 6 & $1^{7}$ \\
\hline very & Strongly & Agree & Neutral & Disagree & Strongly & Very \\
\hline $\begin{array}{c}\text { Strongly } \\
\text { Agree }\end{array}$ & Agree & & & & Disagree & $\begin{array}{l}\text { Strongly } \\
\text { Disagree }\end{array}$ \\
\hline
\end{tabular}

14. I think that personal answers to a computer health survey would be kept in stricter confidence than answers to a doctor's survey.

\begin{tabular}{|c|c|c|c|c|c|c|}
\hline $1^{1}$ & $f^{2}$ & $1^{3}$ & $1^{4}$ & $1^{5}$ & $1^{6}$ & $1^{7}$ \\
\hline very & Strongly & Agree & Neutral & Disagree & Strongly & Very \\
\hline $\begin{array}{c}\text { Strongly } \\
\text { Agree }\end{array}$ & Agree & & & & Disagree & $\begin{array}{l}\text { Strongly } \\
\text { Disagree }\end{array}$ \\
\hline
\end{tabular}


15. The use of computers in keeping crime statistics benefits the public.

\begin{tabular}{|c|c|c|c|c|c|c|}
\hline $1^{1}$ & $1^{2}$ & $j^{3}$ & $1^{4}$ & $j^{5}$ & $1^{6}$ & $1^{7}$ \\
\hline very & Strongly & Agree & Teutral & Disagree & Strongly & Very \\
\hline $\begin{array}{c}\text { Strongly } \\
\text { Agree }\end{array}$ & Agree & & & & D1sagree & $\begin{array}{l}\text { Strongly } \\
\text { Disagree }\end{array}$ \\
\hline
\end{tabular}

16. There are more 1mportant things to consider about financial transactions than the speed a computer can give.

$\begin{array}{ccccccc}1^{1} & 1^{2} & 1^{3} & 1^{4} & 1^{5} & 1^{6} & 1^{7} \\ \begin{array}{c}\text { Strongly } \\ \text { Agree }\end{array} & \begin{array}{c}\text { Strongly } \\ \text { Agree }\end{array} & \text { Agree } & \text { Neutral } & \text { D1sagree } & \begin{array}{c}\text { Strongly } \\ \text { Disagree }\end{array} & \begin{array}{l}\text { Strongly } \\ \text { Disagree }\end{array}\end{array}$

17. No matter how much soclety uses computers, the mental capacity of society will remai as good as ever.

\begin{tabular}{|c|c|c|c|c|c|c|}
\hline 1 & $1^{2}$ &, 3 & $1^{4}$ & $1^{5}$ & $1^{6}$ & $1^{7}$ \\
\hline Very & Strongly & tigree & Neutral & Disagree & Strongly & Very \\
\hline $\begin{array}{c}\text { Strongly } \\
\text { Agree }\end{array}$ & Agree & & & & Disagree & $\begin{array}{l}\text { Strongly } \\
\text { Disagree }\end{array}$ \\
\hline
\end{tabular}

18. I would feel more in control discussing my problems with a counselor than with a computer.

\begin{tabular}{|c|c|c|c|c|c|c|}
\hline $1^{1}$ & $1^{2}$ & $1^{3}$ & $1^{4}$ & $1^{5}$ & $1^{6}$ & $1^{7}$ \\
\hline very & Strongly & Agree & Neutral & Disagree & Strongly & Very \\
\hline $\begin{array}{c}\text { Strongly } \\
\text { Agree }\end{array}$ & Agree & & & & Disagree & $\begin{array}{l}\text { Strongly } \\
\text { Disagree }\end{array}$ \\
\hline
\end{tabular}

19. The computer's lightening swift calculating ability and nearly infinite wewory are entirely desirable.

$\begin{array}{lllllll}1 & 1^{2} & 1^{3} & 1^{4} & 1^{5} & 1^{6} & 1^{7} \\ \begin{array}{c}\text { Very } \\ \begin{array}{c}\text { Strongly } \\ \text { Agree }\end{array}\end{array} & \begin{array}{c}\text { Strongly } \\ \text { Agree }\end{array} & \text { Agree } & \text { Neutral } & \text { Disagree } & \text { Strongly } & \text { Very } \\ \text { Disagree } & \text { Strongly } \\ \text { Disagree }\end{array}$


20. A computer can never match the human contact a teacher provides.
$\frac{1}{\text { very st }}$ Strongly
Agree

$\begin{array}{llllll}1^{2} & 1^{3} & 1^{4} & 1^{5} & 1^{6} & 1^{7} \\ \begin{array}{l}\text { Agrongly } \\ \text { Agree }\end{array} & \text { Agree } & \text { Neutral } & \text { Disagree } & \text { Strongly } & \text { Very } \\ & & & \text { Disagree } & \begin{array}{l}\text { Strongly } \\ \text { Disagree }\end{array}\end{array}$

21. It would be nice if computers didn't always do only what they are programmed to.

$\begin{array}{ccccccc}1 & 1^{2} & 1^{3} & 1^{4} & 1^{5} & 1^{6} & /^{7} \\ \begin{array}{c}\text { Very } \\ \text { Strongly } \\ \text { Agree }\end{array} & \begin{array}{c}\text { Strongly } \\ \text { Agree }\end{array} & \text { Agree } & \text { Neutral } & \text { Disagree } & \text { Strongly } & \text { Very } \\ \text { Disagree } & \begin{array}{c}\text { Strongly } \\ \text { Disagree }\end{array}\end{array}$

22. Too many things could go wrong with a computer that couldn't go wrong with a counselor as I try to solve my personal problems.

$\begin{array}{ccccccc}1 & 1^{2} & 1^{3} & 1^{4} & 1^{5} & 1^{6} & 1^{7} \\ \begin{array}{c}\text { Sery } \\ \text { Strongly } \\ \text { Agree }\end{array} & \begin{array}{c}\text { Strongly } \\ \text { Agree }\end{array} & \text { Agree } & \text { Neutral } & \text { Disagree } & \text { Strongly } & \text { Very } \\ \text { Disagree } & \text { Strongly } \\ \text { Disagree }\end{array}$

23. Computers are valuable because they save people from mental drudgery.

$\begin{array}{ccccccc}1^{1} & 1^{2} & 1^{3} & 1^{4} & 1^{5} & 1^{6} & 1^{7} \\ \begin{array}{c}\text { Very } \\ \text { Agrongly } \\ \text { Agree }\end{array} & \text { Agree } & \text { Agree } & \text { Seutral } & \text { Disagree } & \text { Strongly } & \text { Very } \\ & & & & \text { Disagree } & \text { Strongly } \\ \text { Alsagree }\end{array}$

24. Personal credit information can be kept fust as private and confidential on computers as through any other medium.

\begin{tabular}{|c|c|c|c|c|c|c|}
\hline $1^{1}$ & $1^{2}$ & $1^{3}$ & $1^{4}$ & $j^{5}$ & $1^{6}$ & $j^{7}$ \\
\hline very & Strongly & Agree & Teutral & Disagree & Strongly & Very \\
\hline $\begin{array}{c}\text { Strongly } \\
\text { Agree }\end{array}$ & Agree & & & & Disagree & $\begin{array}{l}\text { Strongly } \\
\text { Disagree }\end{array}$ \\
\hline
\end{tabular}


25. I think it is valuable to have computers to forecast the outcomes of elections.

\begin{tabular}{|c|c|c|c|c|c|c|}
\hline 1 & $1^{2}$ & $1^{3}$ & $1^{4}$ & $1^{5}$ & $1^{6}$ & $\rho^{7}$ \\
\hline very & Strongly & Agree & Neutral & Disagree & Strongly & Very \\
\hline $\begin{array}{c}\text { Strongly } \\
\text { Agree }\end{array}$ & Agree & & & & Disagree & $\begin{array}{l}\text { Strongly } \\
\text { Disagree }\end{array}$ \\
\hline
\end{tabular}

26. The ability to reflect upon personal experience separates man from computers.

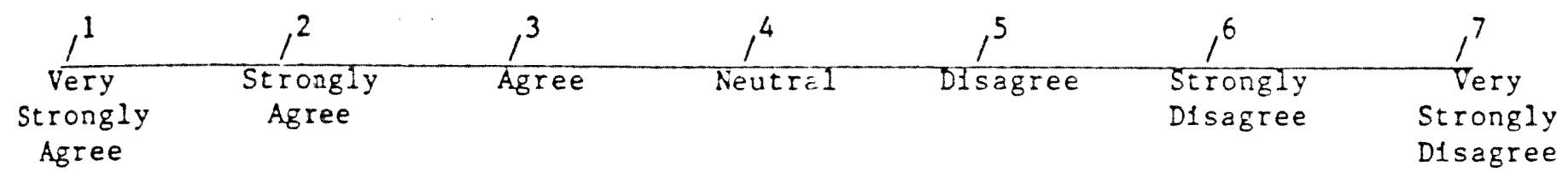

27. Forecasting the outcomes of elections by computers interferes with the election process.

\begin{tabular}{|c|c|c|c|c|c|c|}
\hline 1 & $1^{2}$ & $1^{3}$ & $1^{4}$ & $1^{5}$ & $1^{6}$ &,$^{7}$ \\
\hline very & Strongly & Rigree & Teutral & Disagree & Strongly & Very \\
\hline $\begin{array}{c}\text { Strongly } \\
\text { Agree }\end{array}$ & Agree & & & & Disagree & $\begin{array}{l}\text { Strongly } \\
\text { Disagree }\end{array}$ \\
\hline
\end{tabular}

28. All in all, I would prefer to do math or statistics myself than use a computer.

\begin{tabular}{|c|c|c|c|c|c|c|}
\hline$f^{1}$ & $1^{2}$ & $1^{3}$ & $1^{4}$ & $i^{5}$ & $1^{6}$ & $1^{7}$ \\
\hline very & Strongly & Agree & Neutral & Disagree & Strongly & Very \\
\hline $\begin{array}{c}\text { Strongly } \\
\text { Agree }\end{array}$ & Agree & & & & Disagree & $\begin{array}{l}\text { Strongly } \\
\text { Disagree }\end{array}$ \\
\hline
\end{tabular}

29. The use of computers to record personal credit information increases the possibility of other people getting hold of personal information about me.
$1^{1}$
$\begin{gathered}\text { Very } \\ \text { Strongly } \\ \text { Agree }\end{gathered}$
Atrongl
Agree
$\frac{1^{3}}{\text { Agree }}$
$\frac{1^{4}}{\text { Neutral }}$
$\frac{1^{5}}{\text { Disagree }}$
Disagree Strongly
$\frac{1^{6}}{\text { Strongly }}$
$\frac{1}{T e}^{7}$
Strongly
Disagree 
30. It would be desirable to learn statistics from a computer because most statistics are calculated on computers.

\begin{tabular}{|c|c|c|c|c|c|c|}
\hline $1^{1}$ & $1^{2}$ & $1^{3}$ & $1^{4}$ & $1^{5}$ & $1^{6}$ & $1^{7}$ \\
\hline very & Serongly & Agree & Teutral & Disagree & Strongly & Very \\
\hline $\begin{array}{c}\text { Strongly } \\
\text { Agree }\end{array}$ & Agree & & & & Disagree & $\begin{array}{l}\text { Strongly } \\
\text { Disagree }\end{array}$ \\
\hline
\end{tabular}

31. People have begun to rely too heav1ly upon computer.

\begin{tabular}{|c|c|c|c|c|c|c|}
\hline 1 & $j^{2}$ & $j^{3}$ & $1^{4}$ & $i^{5}$ & $1^{6}$ & $1^{7}$ \\
\hline very & Strongly & Agree & Neutral & Disagree & Strengly & Very \\
\hline $\begin{array}{c}\text { Strongly } \\
\text { Agree }\end{array}$ & Agree & & & & Disagree & $\begin{array}{l}\text { Strongly } \\
\text { Disagree }\end{array}$ \\
\hline
\end{tabular}

32. Credit and other financial transactions are faster when done through a conputer than when done through people.

\begin{tabular}{|c|c|c|c|c|c|c|}
\hline 1 & $/^{2}$ & $1^{3}$ & $1^{4}$ & $1^{5}$ & $1^{6}$ & $1^{7}$ \\
\hline$\sqrt{e r y}$ & Strongly & Agree & Feutral & Disagree & Strongly & Tery \\
\hline $\begin{array}{c}\text { Strongly } \\
\text { Agree }\end{array}$ & Agree & & & & Disagree & $\begin{array}{l}\text { Strongly } \\
\text { Disagree }\end{array}$ \\
\hline
\end{tabular}

33. My rights are more easily violated when computers store personal credit information about ne.

$\begin{array}{ccccccc}1 & 1^{2} & 1^{3} & 1^{4} & 1^{5} & 1^{6} & 1^{7} \\ \begin{array}{l}\text { Very } \\ \text { Strongly }\end{array} & \text { Strongly } & \text { A.gree } & \text { Neutral } & \text { Disagree } & \text { Strongly } & \text { Very } \\ \text { Agree } & \text { Afree } & & & \text { Disagree } & \text { Strongly } \\ \text { Disagree }\end{array}$

34. I have more confldence when votes are counted by a computer than when they are counted by an election official.

$\begin{array}{ccccccc}1 & 1^{2} & 1^{3} & 1^{4} & j^{5} & /^{6} & /^{7} \\ \begin{array}{l}\text { Very } \\ \begin{array}{c}\text { Strongly } \\ \text { Agree }\end{array}\end{array} & \begin{array}{c}\text { Strongly } \\ \text { Agree }\end{array} & \text { Agree } & \text { Neutral } & \text { Disagree } & \text { Strongly } & \text { Very } \\ \text { Disagree } & \text { Strongly } \\ \text { Disagree }\end{array}$


35. I would like learning from a computer because I wouldn't feel embarrassed when I didn't know the answer.

$\begin{array}{ccccccc}\frac{1}{\text { Very }} & 1^{2} & 1^{3} & 1^{4} & 1^{5} & 1^{6} & 1^{7} \\ \begin{array}{c}\text { Strongly } \\ \text { Agree }\end{array} & \begin{array}{c}\text { Agree } \\ \text { Agrigly }\end{array} & \text { Agree } & \text { Neutral } & \text { Disagree } & \text { Strongly } & \text { Very } \\ \text { Disagree } & \text { Strongly } \\ \text { Disagree }\end{array}$

36. The crime statistics kept on computers are too misleading to be much good.

$\begin{array}{ccccccc}1 & 1^{2} & 1^{3} & 1^{4} & 1^{5} & 1^{6} & 1^{7} \\ \begin{array}{c}\text { Very } \\ \text { Strongly } \\ \text { Agree }\end{array} & \begin{array}{c}\text { Strongly } \\ \text { Agree }\end{array} & \text { Agree } & \text { Neutral } & \text { Disagree } & \text { Strongly } & \text { Very } \\ \text { Disagree } & \text { Strongly } \\ \text { Disagree }\end{array}$

37. Computers are beginning to make us less human.

\begin{tabular}{|c|c|c|c|c|c|c|}
\hline$\rho^{1}$ & $1^{2}$ & $j^{3}$ & $1^{4}$ & $1^{5}$ & $1^{6}$ & $1^{7}$ \\
\hline$\sqrt{\text { ery }}$ & Strongly & Agree & Neutral & Disagree & Strongly & Very \\
\hline $\begin{array}{c}\text { Strongly } \\
\text { Azree }\end{array}$ & Agree & & & & Disagree & $\begin{array}{l}\text { Strongly } \\
\text { Disagree }\end{array}$ \\
\hline
\end{tabular}

38. Even conputers should use discretionary fudgment in solving soclal problems.

\begin{tabular}{|c|c|c|c|c|c|c|}
\hline 1 & $1^{2}$ & 3 & $1^{4}$ &, 5 & 6 & $1^{7}$ \\
\hline very & Strongly & Agree & Neutral & Disagree & Strongly & Very \\
\hline Strongly & Agree & & & & Disagree & Strongly \\
\hline Agree & & & & & & Disagree \\
\hline
\end{tabular}

39. There is really no reason to fear computers.
$\frac{1}{\sqrt{\text { ery }}}$
Strongly
Agree
$\frac{1^{3}}{\text { Agree }}$
Agree
$\frac{1^{4}}{\text { Neutral }}$
Neutral Disagree

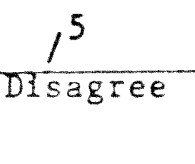

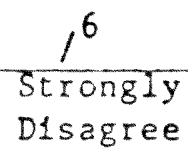
$1^{7}$
Very
Strongly
Disagree 
40. I would rather talk to a counselor than try to solve my personal problems with a computer.

$\begin{array}{ccccccc}1^{1} & 1^{2} & 1^{3} & 1^{4} & /^{5} & /^{6} & 1^{7} \\ \begin{array}{c}\text { Vtrongly } \\ \text { Agree }\end{array} & \begin{array}{c}\text { Strongly } \\ \text { Agree }\end{array} & \text { Agree } & \text { Neutral } & \text { Disagree } & \text { Strongly } & \text { Very } \\ \text { Disagree } & \begin{array}{c}\text { Strongly } \\ \text { Disagree }\end{array}\end{array}$

41. Compared with a counselor, a computer would be more patient and reliable in helping to solve a personal problem.

\begin{tabular}{|c|c|c|c|c|c|c|}
\hline 1 & $j^{2}$ & $i^{3}$ & $1^{4}$ & $j^{5}$ & $1^{6}$ & $1^{7}$ \\
\hline very & Strongly & Agree & Neutral & Disagree & Strongly & Very \\
\hline $\begin{array}{c}\text { Strongly } \\
\text { Agree }\end{array}$ & Agree & & & & Disagree & $\begin{array}{l}\text { Strongly } \\
\text { Disagree }\end{array}$ \\
\hline
\end{tabular}

42. I would be nore honest when answering questions about my health frop a doctor than from a computer.

\begin{tabular}{|c|c|c|c|c|c|c|}
\hline 1 & $f^{2}$ & $j^{3}$ & $1^{4}$ & $1^{5}$ & $1^{6}$ & $1^{7}$ \\
\hline very & Strongly & Agree & Neutral & Disagree & Strongly & Very \\
\hline $\begin{array}{c}\text { Strongly } \\
\text { Agree }\end{array}$ & Agree & & & & Disagree & $\begin{array}{l}\text { Strongly } \\
\text { Disagree }\end{array}$ \\
\hline
\end{tabular}

43. I would use more caution in using computer-calculated statistics than hand-calculated statistics.



44. A counselor could know me better than a computer ever could.

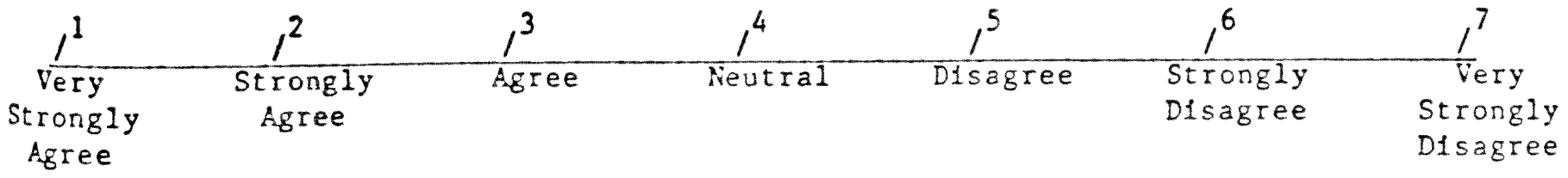


45. I would feel more at ease solving a personal problem with a computer than with a counselor.

\begin{tabular}{|c|c|c|c|c|c|c|}
\hline $1^{1}$ & $1^{2}$ & $1^{3}$ & $1^{4}$ & $1^{5}$ & $1^{6}$ & 17 \\
\hline very & Strongly & Agree & Teutral & Disagree & Strongly & Very \\
\hline $\begin{array}{l}\text { Strongly } \\
\text { Agree }\end{array}$ & Agree & & & & Disagree & $\begin{array}{l}\text { Strongly } \\
\text { Disagree }\end{array}$ \\
\hline
\end{tabular}

46. I could not be sure who would see my answers to a computer health survey.

\begin{tabular}{|c|c|c|c|c|c|c|}
\hline 1 & $1^{2}$ & $1^{3}$ & $1^{4}$ & $j^{5}$ & $1^{6}$ & $1^{7}$ \\
\hline very & Strongly & Agree & Neutral & Disagree & Strongly & Very \\
\hline $\begin{array}{c}\text { Strongly } \\
\text { Agree }\end{array}$ & Agree & & & & D1sagree & $\begin{array}{l}\text { Strongly } \\
\text { Disagree }\end{array}$ \\
\hline
\end{tabular}

47. Compared with the industrial revolution, the computer is less threatening to society.

$\begin{array}{ccccccc}1 & /^{2} & /^{3} & /^{4} & /^{5} & 1^{6} & /^{7} \\ \begin{array}{c}l_{\text {Very }} \\ \text { Strongly } \\ \text { Agree }\end{array} & \begin{array}{c}\text { Strongly } \\ \text { Agree }\end{array} & \text { Agree } & \text { Neutral } & \text { Disagree } & \text { Strongly } & \text { Very } \\ \text { Disagree } & \text { Strongly } \\ \text { Disagree }\end{array}$

48. Inaccuracy is often the price pald for the speed and memory of a computer.

$\begin{array}{lllllll}1 & 1^{2} & 1^{3} & 1^{4} & 1^{5} & 1^{6} & 1^{7} \\ \begin{array}{c}\text { Very } \\ \text { Agree }\end{array} & \begin{array}{c}\text { Strongly } \\ \text { Agree }\end{array} & \text { Agree } & \text { Neutral } & \text { Disagree } & \text { Strongly } & \text { Very } \\ \text { Disagree } & \text { Strongly } \\ \text { Disagree }\end{array}$

49. I feel that a computer health survey would be more systematic than a health survey taken by a doctor.

\begin{tabular}{|c|c|c|c|c|c|c|}
\hline $1^{1}$ & $j^{2}$ & $1^{3}$ & $1^{4}$ & $1^{5}$ & $1^{6}$ & $1^{7}$ \\
\hline$\sqrt{\text { ery }}$ & Strongly & Agree & Neutral & Disagree & Strongly & Very \\
\hline $\begin{array}{c}\text { Strongly } \\
\text { Agree }\end{array}$ & Agree & & & & D1sagree & $\begin{array}{l}\text { Strongly } \\
\text { Disagree }\end{array}$ \\
\hline
\end{tabular}


50. When a computer instantaneously reports public opinion, both citizens and government benefit.
$\frac{1}{\sqrt{e r y}-S t}$
$1^{2} \quad /^{3}$
$\frac{1^{4}}{\text { Neutral Disagree }}$
Agree
Strongly
Agree

\begin{tabular}{ll}
$1^{6}$ & $1^{7}$ \\
\hline Strongly & Very \\
Disagree & Strongly \\
& Disagree
\end{tabular}

51. I feel safer knowing the police can use the computer's high speed and extensive memory to help in the apprehension of criminals.

\begin{tabular}{|c|c|c|c|c|c|c|}
\hline $1^{1}$ & $j^{2}$ & $1^{3}$ & $1^{4}$ & $1^{5}$ & $1^{6}$ & $1^{7}$ \\
\hline very & Strongly & Agree & Neutral & Disagree & Strongly & Very \\
\hline $\begin{array}{c}\text { Strongly } \\
\text { Agree }\end{array}$ & Agree & & & & Disagree & $\begin{array}{l}\text { Strongly } \\
\text { Disagree }\end{array}$ \\
\hline
\end{tabular}

52. When a computer keep records of contributions to politicians, elections are made fairer.

$\begin{array}{lllllll}1 & 1^{2} & 1^{3} & 1^{4} & 1^{5} & 1^{6} & 1^{7} \\ \begin{array}{c}\text { Very } \\ \text { Strongly } \\ \text { Agree }\end{array} & \begin{array}{c}\text { Strongly } \\ \text { Agree }\end{array} & \text { Agree } & \text { Keutral } & \text { Disagree } & \text { Strongly } & \text { Very } \\ \text { Disagree } & \text { Strongly } \\ \text { Disagree }\end{array}$

53. It does not watter that computers cannot reflect upon the meaning of their personal experience.

\begin{tabular}{|c|c|c|c|c|c|c|}
\hline $1^{1}$ & $1^{2}$ & $1^{3}$ & $1^{4}$ & $1^{5}$ & $1^{6}$ & $1^{7}$ \\
\hline Very & Strongly & Agree & Neutral & Disagree & Strongly & Very \\
\hline $\begin{array}{c}\text { Strongly } \\
\text { Agree }\end{array}$ & Agree & & & & D1sagree & $\begin{array}{l}\text { Strongly } \\
\text { Disagree }\end{array}$ \\
\hline
\end{tabular}

54. Reporting public opinion by computer may interfere with the functioning of the government.

$\begin{array}{ccccccc}1 & 1^{2} & 1^{3} & 1^{4} & 1^{5} & 1^{6} & 1^{7} \\ \begin{array}{c}\text { Sery } \\ \text { Agroly } \\ \text { Agree }\end{array} & \begin{array}{c}\text { Strongly } \\ \text { Agree }\end{array} & \text { Agree } & \text { Neutral } & \text { Disagree } & \text { Strongly } & \text { Very } \\ \text { Disagree } & \begin{array}{c}\text { Strongly } \\ \text { Disagree }\end{array}\end{array}$


55. I would feel wore Independent solving a personal problem on a computer than with a counselor.

\begin{tabular}{|c|c|c|c|c|c|c|}
\hline 1 & $1^{2}$ & $j^{3}$ & $1^{4}$ & $1^{5}$ & $1^{6}$ & $7^{7}$ \\
\hline$\sqrt{e r y}$ & Strongly & Agree & Neutral & Drsagree & Strongly & Very \\
\hline $\begin{array}{c}\text { Strongly } \\
\text { Agree }\end{array}$ & Agree & & & & Disagree & $\begin{array}{l}\text { Strongly } \\
\text { Disagree }\end{array}$ \\
\hline
\end{tabular}

56. Learning from a computer would be a cold 1mpersonal experience.

$\begin{array}{lllllll}1 & 1^{2} & 1^{3} & 1^{4} & 1^{5} & 1^{6} & 1^{7} \\ \begin{array}{c}\text { Very } \\ \text { Strongly } \\ \text { Agree }\end{array} & \begin{array}{c}\text { Strongly } \\ \text { Agree }\end{array} & \text { Agree } & \text { Neutral } & \text { Disagree } & \text { Strongly } & \text { Very } \\ \text { Disagree } & \text { Strongly } \\ \text { Disagree }\end{array}$

57. As compared with people, computers are more accurate in keeping records of personal financial transactions.
$\frac{1^{1}}{\text { Very }} \frac{1^{2}}{\text { Strongly }}$
Strongly
Agree
$\frac{1^{5}}{\text { Disagree }} \frac{1^{6}}{\text { Strongly }}$
Disagree

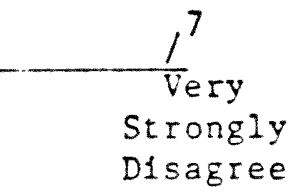
Agree

$\begin{array}{llll}1^{4} & 1^{5} & 1^{6} & 1^{7} \\ & \text { Disagral } & \text { Visagree } & \text { Strongly } \\ & & \text { Disagree }\end{array}$

58. Statistics should be learned and understood before a computer is used for their calculation.

$\begin{array}{lllllll}l^{1} & 1^{2} & 1^{3} & 1^{4} & 1^{5} & 1^{6} & \left.\right|^{7} \\ \begin{array}{c}\text { Very } \\ \text { trongly } \\ \text { Agree }\end{array} & \begin{array}{c}\text { Strongly } \\ \text { Agree }\end{array} & \text { Agree } & \text { Neutral } & \text { Disagree } & \text { Strongly } & \text { Very } \\ \text { Disagree } & \text { Strongly } \\ \text { Disagree }\end{array}$

59. I would feel wore at ease learning from a computer than from a teacher.

\begin{tabular}{|c|c|c|c|c|c|c|}
\hline 1 & $j^{2}$ & $1^{3}$ & $1^{4}$ & $i^{5}$ & $1^{6}$ & $i^{7}$ \\
\hline very & Strongly & Agree & Neutral & Disagree & Strongly & Very. \\
\hline $\begin{array}{c}\text { Strongly } \\
\text { Agree }\end{array}$ & Agree & & & & Disagree & $\begin{array}{l}\text { Strongly } \\
\text { D1sagree }\end{array}$ \\
\hline
\end{tabular}


60. Computers 1ncrease the complexity of modern 11fe.

\begin{tabular}{|c|c|c|c|c|c|c|}
\hline $1^{1}$ & $1^{2}$ & $1^{3}$ & $1^{4}$ & $1^{5}$ & $1^{6}$ & $j^{7}$ \\
\hline very & Strongly & Agree & Neutral & Disagree & Strongly & Very \\
\hline $\begin{array}{c}\text { Strongly } \\
\text { Agree }\end{array}$ & Agree & & & & Disagree & $\begin{array}{l}\text { Strongly } \\
\text { Disagree }\end{array}$ \\
\hline
\end{tabular}

61. It is good that computers only do what they are programmed to do.

\begin{tabular}{|c|c|c|c|c|c|c|}
\hline 1 & $i^{2}$ & $1^{3}$ & $1^{4}$ & $i^{5}$ & 6 & 7 \\
\hline very & Strongly & Agree & Neutral & Disagree & Strongly & Very \\
\hline Strongly & Agree & & & & Disagree & $\begin{array}{l}\text { Strongly } \\
\text { Disagree }\end{array}$ \\
\hline
\end{tabular}

62. A computer can never replace the experience and intultion of a good doctor.

\begin{tabular}{|c|c|c|c|c|c|c|}
\hline 1 & $1^{2}$ & $j^{3}$ & $1^{4}$ & $1^{5}$ & $1^{6}$ & $1^{7}$ \\
\hline$\sqrt{\text { ery }}$ & Strongly & Agree & Keutral & Disagree & Strongly & Very \\
\hline $\begin{array}{c}\text { Strongly } \\
\text { Agree }\end{array}$ & Agree & & & & Disagree & $\begin{array}{l}\text { Strongly } \\
\text { Disagree }\end{array}$ \\
\hline
\end{tabular}

63. Learning concepts on the computer sacrifices chlldren's grasp of the meaning of these concepts.

$\begin{array}{ccccccc}1 & 1^{2} & 1^{3} & 1^{4} & 1^{5} & 1^{6} & 1^{7} \\ \begin{array}{ccc}\text { Very } \\ \text { Strongly } \\ \text { Agree }\end{array} & \begin{array}{c}\text { Strongly } \\ \text { Agree }\end{array} & \text { Agree } & \text { Neutral } & \text { Disagree } & \text { Strongly } & \text { Very } \\ \text { Strongly } & & & & \text { Disagree } & \text { Stisagree }\end{array}$

34. I do not think my freedom is reduced by the widespread use of computers in the justice sytem.
$\frac{1^{1}}{\text { very }} \frac{1^{2}}{\text { Strongl }}$
Strongly
Agree
$\frac{1^{3}}{\text { Agree }} \quad \frac{1^{4}}{\text { Neutral }} \frac{1^{5}}{\text { Disagree }}$
$\frac{1^{3}}{\text { Agree }} \quad \frac{1}{4}_{\text {Neutral }} \frac{1}{5}^{5}$
Agree
$\frac{1^{6}}{\text { Strongly }}$
Disagree

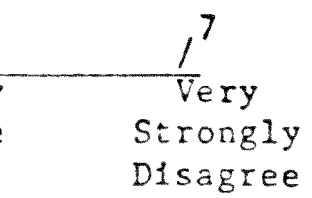


65. Just because people use a computer for arithmet1c problems does not mean people w111 forget how to do arithmetic problems.

\begin{tabular}{|c|c|c|c|c|c|c|}
\hline $1^{1}$ & $/^{2}$ & $1^{3}$ & $1^{4}$ & $1^{5}$ & $1^{6}$ & $1^{7}$ \\
\hline very & Strongly & Agree & Neutral & Drsagree & Strongly & $\frac{1}{\text { Very }}$ \\
\hline $\begin{array}{c}\text { Strongly } \\
\text { Agree }\end{array}$ & Agree & & & & Disagree & $\begin{array}{l}\text { Strongly } \\
\text { Disagree }\end{array}$ \\
\hline
\end{tabular}

66. Computers can never match the accuracy of trained people in keeping records of financlal transactions.

\begin{tabular}{|c|c|c|c|c|c|c|}
\hline $1^{1}$ & $1^{2}$ & $1^{3}$ & $1^{4}$ & $1^{5}$ & $1^{6}$ & $1^{7}$ \\
\hline very & Strongly & Agree & Neutral & Disagree & Strongly & Very \\
\hline $\begin{array}{c}\text { Strongly } \\
\text { Agree }\end{array}$ & Agree & & & & Disagree & $\begin{array}{l}\text { Strongly } \\
\text { Disagree }\end{array}$ \\
\hline
\end{tabular}

67. It is too easy to wake a mlstake and harm an innocent person when conputers are used in the fustice system.

\begin{tabular}{|c|c|c|c|c|c|c|}
\hline 1 & $j^{2}$ & $j^{3}$ & $1^{4}$ &,$^{5}$ & $1^{6}$ & $j^{7}$ \\
\hline Very & StrongIy & Ágree & Neutral & Dlsagree & Strongly & Very \\
\hline $\begin{array}{c}\text { Strongly } \\
\text { Agree }\end{array}$ & Agree & & & & Disagree & $\begin{array}{l}\text { Strongly } \\
\text { Disagree }\end{array}$ \\
\hline
\end{tabular}

68. I would be more at ease answering health questions from a computer than from a doctor.
$\frac{1}{\text { Very }}$
Arongly
Agree

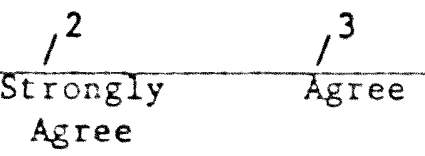
$\frac{1^{4}}{\text { Seutral }}$

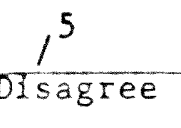
Disagree Strongly
Disagree

$\begin{array}{ll}\frac{1}{6} & /^{7} \\ \text { Disagree } & \text { Tery } \\ & \text { Disagree }\end{array}$

69. The complexity of the problems of modern soclety require computers for their solutions.

\begin{tabular}{|c|c|c|c|c|c|c|}
\hline $1^{1}$ & $/^{2}$ & $1^{3}$ & $1^{4}$ & $1^{5}$ & $1^{6}$ & $j^{7}$ \\
\hline $\begin{array}{l}\text { Very } \\
\text { Strongly } \\
\text { Agree }\end{array}$ & $\begin{array}{c}\text { Strongly } \\
\text { Asree }\end{array}$ & Agree & Neutral & Disagree & $\begin{array}{l}\text { Strongly } \\
\text { D1sagree }\end{array}$ & $\begin{array}{l}\text { Very } \\
\text { Strongly } \\
\text { Disagree }\end{array}$ \\
\hline
\end{tabular}


70. The widespread use of computers in the fustice system violates my rights.

$\begin{array}{lllllll}/^{1} & /^{2} & /^{3} & /^{4} & /^{5} & /^{6} & /^{7} \\ \begin{array}{c}\text { Strongly } \\ \text { Agree }\end{array} & \begin{array}{c}\text { Strongly } \\ \text { Agree }\end{array} & \text { Agree } & \text { Neutral } & \text { Disagree } & \text { Strongly } & \text { Very } \\ \text { Disagree } & \text { Strongly } \\ \text { Disagree }\end{array}$

71. A computer simply cannot increase a person's mental abilities.

$\begin{array}{ccccccc}1 & 1^{2} & /^{3} & 1^{4} & 1^{5} & 1^{6} & 1^{7} \\ \begin{array}{c}\text { Very } \\ \begin{array}{c}\text { Songly } \\ \text { Agree }\end{array}\end{array} & \begin{array}{c}\text { Strongly } \\ \text { Agree }\end{array} & \text { Agree } & \text { Neutral } & \text { Disagree } & \text { Strongly } & \text { Very } \\ \text { Disagree } & \text { Strongly } \\ \text { Disagree }\end{array}$

72. Computers increase human freedom and allow us to become more human.

$\begin{array}{lllllll}1^{1} & /^{2} & /^{3} & /^{4} & /^{5} & /^{6} & /^{7} \\ \begin{array}{c}\text { Vtrongly } \\ \text { Agree }\end{array} & \begin{array}{c}\text { Strongly } \\ \text { Agree }\end{array} & \text { Agree } & \text { Neutral } & \text { Disagree } & \text { Strongly } & \text { Very } \\ \text { Disagree } & \begin{array}{c}\text { Strongly } \\ \text { Disagree }\end{array}\end{array}$

73. It is better to solve math or statistics problems by computer than by hand.

\begin{tabular}{|c|c|c|c|c|c|c|}
\hline 1 & $1^{2}$ & $1^{3}$ & $1^{4}$ & $1^{5}$ & $1^{6}$ & $1^{7}$ \\
\hline$\sqrt{e r y}$ & Strongly & Agree & Neutral & Disagree & Strongly & Very \\
\hline $\begin{array}{c}\text { Strongly } \\
\text { Agree }\end{array}$ & Agree & & & & Disagree & $\begin{array}{l}\text { Strongly } \\
\text { Disagree }\end{array}$ \\
\hline
\end{tabular}

74. When computers report the outcomes of elections, the democratic process is made more effective.

$\begin{array}{lllllll}1^{1} & 1^{2} & 1^{3} & 1^{4} & 1^{5} & 1^{6} & 1^{7} \\ \begin{array}{c}\text { Strongly } \\ \text { Agree }\end{array} & \begin{array}{c}\text { Strongly } \\ \text { Agree }\end{array} & \text { Agree } & \text { Neutral } & \text { Disagree } & \text { Strongly } & \text { Visy } \\ \text { Disagree } & \text { Strongly } \\ \text { Disagree }\end{array}$


75. Keeping a computer accounting of political contributions does not deter 11 legal contributions.

\begin{tabular}{|c|c|c|c|c|c|c|}
\hline 1 & $1^{2}$ & $1^{3}$ & $1^{4}$ &,$^{5}$ & 6 & 7 \\
\hline very & Strongly & Ágree & Neutral & Dlsagree & Strongly & $\frac{1}{\text { Very }}$ \\
\hline $\begin{array}{l}\text { Strongly } \\
\text { Agree }\end{array}$ & Agree & & & & D1sagree & $\begin{array}{l}\text { Strongly } \\
\text { Disagree }\end{array}$ \\
\hline
\end{tabular}

76. There 1s really no way in which innocent citizens can be harded by the wide use of computers in the fustice system.

$\begin{array}{ccccccc}1 & 1^{2} & 1^{3} & 1^{4} & 1^{5} & 1^{6} & 1^{7} \\ \begin{array}{l}\text { Very } \\ \text { Strongly } \\ \text { Agree }\end{array} & \begin{array}{c}\text { Agree } \\ \text { Agree }\end{array} & \text { Agree } & \text { Neutral } & \text { Disagree } & \text { Strongly } & \text { Very } \\ \text { Disagree } & \text { Strongly } \\ \text { Disagree }\end{array}$

77. What is threatening to soclety is not the computer, but people's use of the computer

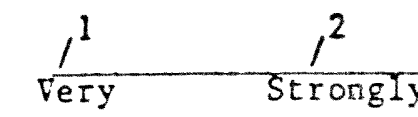
Strongly
Agree
$\frac{1^{4}}{\text { Neutral }}$
Agree
$\frac{1^{5}}{\text { Disagree }}$
Agree
(1)

$\begin{array}{ccc}1^{5} & 1^{6} & 1^{7} \\ \text { Disagree } & \begin{array}{l}\text { Strongly } \\ \text { Disagree }\end{array} & \begin{array}{c}\text { Strongly } \\ \text { Disagree }\end{array}\end{array}$

78. It is not 1mportant that computers do not exercise discretionary judgment over the purpose that way have been intended.

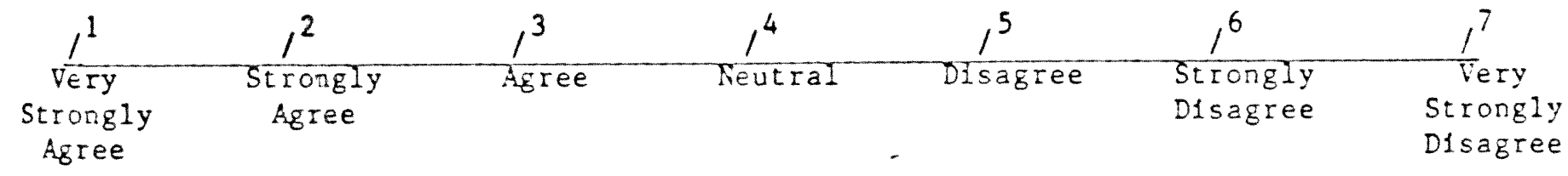

79. I would feel wore comfortable dolng wath or statistics by computer than by hand.
1
Very
trongly
Agree
$1^{2}$
Agree
$\frac{1^{4}}{\text { Neutral }}$
Agree
$\begin{array}{ll}1^{5} & 1^{6} \\ \text { Disagree } & \text { Strongly } \\ \text { Disagree }\end{array}$
Disagree
$\frac{1}{\text { Very }}^{7}$
Strongly
Disagree 
80. As compared with a counselor, a computer could generate a greater number of solutions to my personal problems.

$\begin{array}{ccccccc}I^{1} & 1^{2} & 1^{3} & 1^{4} & 1^{5} & 1^{6} & /^{7} \\ \begin{array}{c}\text { Strongly } \\ \text { Agree }\end{array} & \begin{array}{c}\text { Strongly } \\ \text { Agree }\end{array} & \text { Agree } & \text { Neutral } & \text { Disagree } & \text { Strongly } & \text { Very } \\ \text { Disagree } & \text { Strongly } \\ \text { Disagree }\end{array}$

81. The widespread use of computers in soclety threatens civilization more than any othe innovation.

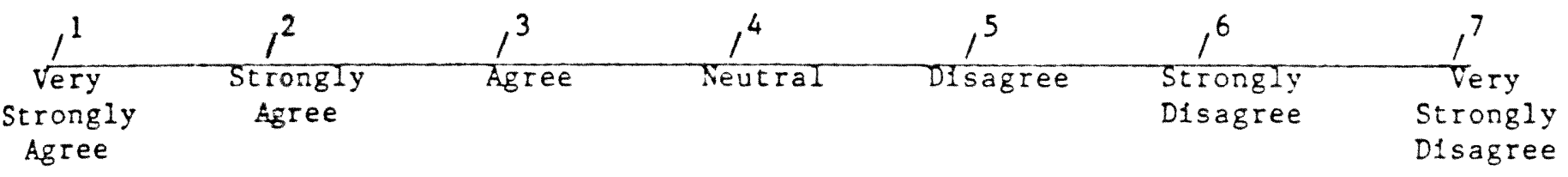

82. I would rather learn from a teacher than from a computer.

\begin{tabular}{|c|c|c|c|c|c|c|}
\hline 1 & $i^{2}$ & $1^{3}$ & $1^{4}$ & $i^{5}$ & $1^{6}$ & $i^{7}$ \\
\hline very & Strongly & Agree & Teutral & Disagree & Strongly & Tery \\
\hline $\begin{array}{c}\text { Strongly } \\
\text { Agree }\end{array}$ & Agree & & & & Disagree & $\begin{array}{l}\text { Strongly } \\
\text { Disagree }\end{array}$ \\
\hline
\end{tabular}

83. I do not think that personal credit information stored in computers will interfere with ry rights to privacy.

$\begin{array}{lcccccc}1 & 1^{2} & 1^{3} & 1^{4} & 1^{5} & 1^{6} & 1^{7} \\ \begin{array}{c}\text { Very } \\ \text { Strongly } \\ \text { Agree }\end{array} & \begin{array}{c}\text { Strongly } \\ \text { Agree }\end{array} & \text { Agree } & \text { Neutral } & \text { Disagree } & \text { Strongly } & \text { Very } \\ \text { Disagree } & \text { Strongly } \\ \text { Disagree }\end{array}$

84. Solving statist1cs or math problems by hand is often better than using the computer to solve these problems.

$\begin{array}{ccccccc}1 & /^{2} & /^{3} & /^{4} & /^{5} & /^{6} & /^{7} \\ \begin{array}{c}\text { Very } \\ \text { Strongly }\end{array} & \text { Strangly } & \text { Agree } & \text { Neutral } & \text { Disagree } & \text { Strongly } & \text { Very } \\ \text { Agree } & \text { Disagree } & \text { Strongly } \\ \text { Disagree }\end{array}$


85. I don't think computers have a place in the fustice system.

\begin{tabular}{|c|c|c|c|c|c|c|}
\hline 1 & $y^{2}$ & $1^{3}$ & $1^{4}$ & $1^{5}$ & $1^{6}$ & 17 \\
\hline$\sqrt{e r y}$ & Strongly & Agree & Neutral & Disagree & Strongly & Very \\
\hline Strongly & Agree & & & & Disagree & Strongly \\
\hline Agree & & & & & & Disagree \\
\hline
\end{tabular}

86. The dependability that a computer provides is more important than the human flexibility that is lost.

$\begin{array}{ccccccc}1^{1} & 1^{2} & 1^{3} & 1^{4} & 1^{5} & 1^{6} & /^{7} \\ \begin{array}{c}\text { Strongly } \\ \text { Agree }\end{array} & \begin{array}{c}\text { Strongly } \\ \text { Agree }\end{array} & \text { Agree } & \text { Neutral } & \text { Disagree } & \text { Strongly } & \text { Very } \\ \text { Disagree } & \begin{array}{l}\text { Strongly } \\ \text { Disagree }\end{array}\end{array}$

87. The more we use computers the more we wlll devalue people's worth.

\begin{tabular}{|c|c|c|c|c|c|c|}
\hline 1 & $i^{2}$ & $1^{3}$ & $1^{4}$ & $i^{5}$ & $1^{6}$ & $1^{7}$ \\
\hline $\begin{array}{c}\text { very } \\
\text { Strongly }\end{array}$ & Strongly & Agree & Neutral & Disagree & Strongly & Very \\
\hline Agree & & & & & & Disagree \\
\hline
\end{tabular}

88. A computer structures the learning situation too much.
$\frac{1^{2}}{\text { Very }} \frac{1^{2}}{\text { Strongly }}$
Agree
$\frac{1^{5}}{\text { Disagree }}$
$!^{6} \quad /^{7}$
Disagree
Strongly
Disagree
Agree

89. If society uses computers too often and too much, the mental capac1ty of society will begin to decrease.
$\frac{1}{\text { Very }}$
Strongly
Agree
$\frac{1^{4}}{\text { Teutral }}$
Agree
$\frac{1^{2}}{\text { Agree }}$
$\frac{1^{5}}{\text { Disagree }}$
Dlsagree Strongly
Disagree

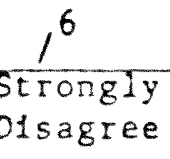




90. The use of the speed and memory of computers to help apprehend criminals does not really help to deter crime.

\begin{tabular}{|c|c|c|c|c|c|c|}
\hline 1 & $2^{2}$ & 3 & $1^{4}$ &,$^{5}$ & 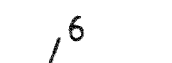 & $i^{7}$ \\
\hline very & Strongly & Agree & Neutral & Disagree & Strongly & Very \\
\hline $\begin{array}{l}\text { Strongly } \\
\text { Agree }\end{array}$ & Agree & & & & Disagree & $\begin{array}{l}\text { Strongly } \\
\text { Disagree }\end{array}$ \\
\hline
\end{tabular}

91. I would not Iike to feel that a computer is swarter than me.

$\begin{array}{ccccccc}1^{1} & 1^{2} & 1^{3} & 1^{4} & 1^{5} & 1^{6} & 1^{7} \\ \begin{array}{c}\text { Vtrongly } \\ \text { Agree }\end{array} & \begin{array}{c}\text { Strongly } \\ \text { Agree }\end{array} & \text { Agree } & \text { Neutral } & \text { Disagree } & \text { Strongly } & \text { Very } \\ \text { Disagree } & \text { Strongly } \\ \text { Disagree }\end{array}$

92. The danger of theft of personal funds is not 1ncreased by the use of computers in banking and credit operations.

$\begin{array}{ccccccc}1 & 1^{2} & 1^{3} & 1^{4} & 1^{5} & 1^{6} & 1^{7} \\ \begin{array}{c}\text { Vtrongly } \\ \text { Agree }\end{array} & \begin{array}{c}\text { Strongly } \\ \text { Agree }\end{array} & \text { Agree } & \text { Neutral } & \text { Disagree } & \text { Strongly } & \text { Very } \\ \text { Disagree } & \text { Strongly } \\ \text { Disagree }\end{array}$

93. I would have wore trust in statistics processed by a computer than by hand.

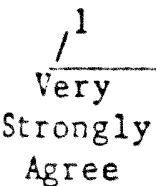
$\frac{1^{3}}{\text { Agree Neutral }}$
Agree
Neutral Disagree
$\frac{1^{5}}{1^{6}} \frac{1^{6}}{\text { Strongree }}$
Disagree
$\frac{1}{\text { Very }}^{7}$
Strongly
Disagree

94. Computers are justiflably feared.

$\begin{array}{lllllll}1 & 1^{2} & 1^{3} & 1^{4} & 1^{5} & 1^{6} & 1^{7} \\ \begin{array}{c}\text { Sery } \\ \text { Agree }\end{array} & \begin{array}{c}\text { Strongly } \\ \text { Agree }\end{array} & \text { Agree } & \text { Neutral } & \text { Disagree } & \text { Strongly } & \text { Very } \\ \text { Disagree } & \text { Strongly } \\ \text { Disagree }\end{array}$


95. Computers can never change the value of belng human.

\begin{tabular}{|c|c|c|c|c|c|c|}
\hline 1 & $j^{2}$ & $1^{3}$ & $1^{4}$ & $1^{5}$ & $1^{6}$ & $1^{7}$ \\
\hline very & Strangly & Agree & Neutral & Disagree & Strongly & Very \\
\hline $\begin{array}{c}\text { Strongly } \\
\text { Agree }\end{array}$ & Agree & & & & Disagree & $\begin{array}{l}\text { Strongly } \\
\text { Disagree }\end{array}$ \\
\hline
\end{tabular}

96. A doctor would be less likely to miss lmportant facts about my health than would a computer.

$\begin{array}{lllllll}1 & 1^{2} & 1^{3} & 1^{4} & 1^{5} & 1^{6} & 1^{7} \\ \begin{array}{c}\text { Very } \\ \text { Strongly } \\ \text { Agree }\end{array} & \begin{array}{c}\text { Strongly } \\ \text { Agree }\end{array} & \text { Agree } & \text { Neutral } & \text { Disagree } & \text { Strongly } & \text { Very } \\ \text { Disagree } & \text { Strongly } \\ \text { Disagree }\end{array}$

97. I would like learning with a computer because I can work at my own pace.

$\begin{array}{ccccccc}1 & 1^{2} & 1^{3} & 1^{4} & 1^{5} & 1^{6} & 1^{7} \\ \begin{array}{c}\text { Very } \\ \text { Strongly } \\ \text { Agree }\end{array} & \begin{array}{c}\text { Strongly } \\ \text { Agree }\end{array} & \text { Agree } & \text { Neutral } & \text { Disagree } & \text { Strongly } & \text { Very } \\ \text { Disagree } & \text { Strongly } \\ \text { Disagree }\end{array}$

98. The most threatening thing about computers is the1r very existence.

\begin{tabular}{|c|c|c|c|c|c|c|}
\hline 1 & $1^{2}$ & $1^{3}$ & $1^{4}$ &,$^{5}$ & $1^{6}$ & $1^{7}$ \\
\hline$\sqrt{e r y}$ & Strongly & Agree & Feutral & Disagree & Strongly & Tery \\
\hline $\begin{array}{l}\text { Strongly } \\
\text { Agree }\end{array}$ & Agree & & & & Disagree & $\begin{array}{l}\text { Strongly } \\
\text { Disagree }\end{array}$ \\
\hline
\end{tabular}


99. People's Dental abilities are actually increased by interacting with the computer.

\begin{tabular}{|c|c|c|c|c|c|c|}
\hline 1 & $f^{2}$ & $1^{3}$ & $1^{4}$ & $j^{5}$ & $1^{6}$ & $1^{7}$ \\
\hline$\sqrt{e r y}$ & Strongly & Agree & Neutral & Disagree & Strongly & Very \\
\hline $\begin{array}{l}\text { Strongly } \\
\text { Agree }\end{array}$ & Agree & & & & Disagree & $\begin{array}{l}\text { Strongly } \\
\text { Disagree }\end{array}$ \\
\hline
\end{tabular}

100. I would feel more independent learning from a computer than learning from a teacher.

\begin{tabular}{|c|c|c|c|c|c|c|}
\hline$f^{1}$ & $t^{2}$ & $i^{3}$ & $1^{4}$ & $f^{5}$ & $1^{6}$ & $i^{7}$ \\
\hline $\begin{array}{l}\text { Very } \\
\text { Sirongly } \\
\text { Agree }\end{array}$ & $\begin{array}{c}\text { Strongly } \\
\text { Agree }\end{array}$ & Agree & Neutral & Drsagree & $\begin{array}{l}\text { Strongly } \\
\text { Disagree }\end{array}$ & $\begin{array}{l}\text { Very } \\
\text { Strongly } \\
\text { Disagree }\end{array}$ \\
\hline
\end{tabular}




\section{APPENDIX " $F "$}

CK. VOCABULARY QUIZ GAME - SUMMARY SHEET

1. Skittisb - A: amusing. B: moving slowly. C: easily frightened. D: silent.

2. impassioned - $A$. full of feeling. B:irresponsible. C: indifferent. D: inert.

3. functional - A: irreplaceable. B: dull. CGpractical. D: pleasurable.

4. dally - A: to fault. $B$ : be indecisive. C: decorate. Dwaste time.

5. rectify- $A$ : to make right. B: break. C: build. D: explain.

6. Cemuneration - $A$ : an act of meditation. B: warning. C: payment. D: honorary degr

7. garnish - A: to harvest. B decorate. C: select. D: strain.

8. cavort - A: to plunge. B: make a change. C: complain. D: leap about.

9. rudimentary - A: impolite. B. basic. C: undefined. D: well-regulated.

10. disclaimer - A: falsehood. B: elaborate speech. C: guarantee. D denial of respo sibility.

11. delectable - A: dainty. B: elaborate. C: healthful. De. delicious.

12. thrive - A: to struggle toward. B: turn. C. prosper. D: pulsate.

13. collateral - A: key. B: Security for a loan.C: proposal. D: secret agreement

14. subtle - A. not obvious. B: graceful. C: restrained. D: well-mansered.

15. mainstay - A: trend. B: stimulant. C. chief support. D: conclusion.

16. yen - A longing for. B: Chinese sail. C: objection. D: approval.

17. apprehension - A: prediction. B: desire for approval. C: persecution. DE: feeling anxiety.

18. Surrogate - 4: hidien entrance.B: lawyer.C: usher.0. substitute

19. coddle - A: to ridicule. B: pamper $C$ : restrain. Di mislead.

20. inkling - A: blemish. B: darkness. C. hint. D: tiny object.

TOT. TIME TO

EARNED

COHPLETE

MIIT. SEC. 
APPENDIX "G"

"THE VOCABULARY QUIZ GAME"

WARM-UP

NAME 
VOCABULARY QUUIZ GAME

WHAT DOES "ICE" MEAI?

WHAT IS THIS WORD WORTH?

$\$$ WRITE IN THE AMMOUNT, AND THEN TURN TO THE NEXT PAGE. 
VOCABULARY ZUIZ GAME

REMOVE THE PAPER AND CIRCLE YOUR ANSWER CHOICE:

WHAT DOES "ICE" MEAN?

A: COLD HARD WHTER

B: USE IT TO CATCH FISH

C: TWO TIMES

D: THE FATTY PART OF MILK

AFTER YOU CIRCLE YOUR CHOICE, TURH TO THE NEXT PAGE. 
VOCABULARY QUIZ GAME

WHAT DOES "WOOD" MEAL?

WHAT IS THIS WORD WORTH?

$\$$ _ WRITE IN THE AMOUNT, AND THEN TURN TO THE NEXT PAGE. 
VOCABULARY ڤUIZ GAME

REUOVE THE PAPER AND CIRCLE YOUR ANSWER CHOICE:

WHAT DOES "WOOD" MEAN?

A: SOMETHING FUN TO DO

B: A CAR

C: A HOLE

D: MADE FROM TREES

AFTER YOU CIRCLE YOUR CHOICE, TURN TO THE NEXT PAGE. 
VOCABULARY QUIZ GAME

WHAT DOES "DRY" MEAN?

WHAT IS THIS WORD WORTH?

$\$$ WRITE IN THE AMMOUNT, AND THEN TUR: TO THE NEXT PAGE. 
VOCABULARY ZUIZ GAME

REMOVE THE PAPER AND CIRCLE YOUR ANSWER CHOICE:

WHAT DOES "DRY" MEAN?

A: NOT EASY

$B$ : NOT WET

C: NOT NEAR

D: NOT WELL

AFTER YOU CIRCLE YOUR CHOICE, TURN TO THE VEXT PAGE. 


\section{REFERENCES}

Ansley, J. (1985). [Attitudes of college students toward computers: CAS scores]. Unpublished data.

Ansley, J. (1986). Machine experience survey. Unpublished manuscript.

Aron, Helen (1982, December) The impact of computers on literacy. Lifelong Learning: The Adult Years, 8-9. Baltes, M.M. and Baltes, P.B., (1982). Microanalytical research on environmental factors and plasticity in psychological aging. In Field, T.M., Huston, A., Quay, H.C., Troll, L., Finley, G.E. (eds), Review of Human Development. New York: Wiley -Interscience, 1982.

Baltes, P. and Goulet, L. (1971). Exploration of development parameters by manipulation and simulation of age differences in behavior. Human Development, 14, 149170.

Bleiszner, R., Willis, S., and Baltes, P. (1981). Training research in aging on the fluid ability of inductive reasoning. Journal of Applied Developmental Psychology, 2, 247-265.

Botwinick, J. (1966). Cautiousness in advanced age. Journal of Gerontology, 21, 347-353.

Canestrari, R.E., Jr. (1963). Paced and self-paced learning in young and elderly adults. Journal of Gerontology, $18,165-168$. 
Carnegie Commission on Higher Education (1973). Priorities

for action: Final Report. New York: McGraw-Hill.

Commission on Non-Traditional Study (1973). Diversity by

Design. San Francisco: Jossey-Bass Publishers.

Computers Snare a New Generation (1985, Mar. 23). Miami

Herald, p. IB.

Condreay, V. and Condreay, R. (1984). Introducing computer

technology to institutionalized elderly.

Gerontologist, $24,186$.

Danowski, J. and Sacks, W. (1980). Computer communication and the elderly. Experimental Aging Research, 6, No. $2,125-135$.

Dickerson, M. and Gentry, J. (1983). Characteristics of adoptors and non-adoptors of home computers. Journal of Consumer Research, 10, 225-235.

Edutek corporation (1985). Vocabulary quiz [computer program]. Cambridge, CA: Author.

Elwood, D. (1969). Automation of psychological testing. American Psychologist, 24, 287-289.

Fiske, E. (1985, April 14). Wave of Curriculum Change Sweeping American Colleges. The New York Times. p. $24 \mathrm{E}$.

Hirschman, E. (1980). Innovativeness, novelty seeking, and consumer creativity. Journal of Consumer Research, 7, 283-295.

Hofferber, M. (1986, June/July). The Natural Intelligence of Raymond Kurzwell. Amtrak Express, pp. 42-45. 
Hoot, J. and Hayslip, B. (1983). Microcomputers and the elderly: New directions for self-sufficiency and lifelong learning. Educational Gerontology, 9, No. 5-6, 493-499.

Jamison, D., Suppes, P. and Wells, S. (1974). The effectiveness of alternative instructional media: a survey. Review of Educational Research, 44, 1-61.

Jaycox, K. and Hicks, B. (1976, September) Elders, students and Computers - Background Information. Illinois Series on Educational Technology of Computers. Number 8 .

Johnson, D. and Mihal, W. (1973). Performance of blacks and whites in computerized versus manual testing environments. American Psychologist, 28, 694-699.

Kinsbourne, M. and Berryhill, J.L. (1972). The nature of interaction between pacing and the age decrement in learning. Journal of Gerontology, 27, 279-284.

Krauss, I., Kenyon, D., Charette, M., Familant, M., Hoyer, W. (1983). Attitudes toward computers-age and experience as moderators. Gerontologist, 23, 201. Kulik, J., Kulik, C., and Cohen, P. (1980). Effectiveness of computer-based college teaching: a meta-analysis of findings. Review of Educational Research, 50, No. 4, $525-544$.

Lawrence Hall of Science (1981). What's for lunch [Computer program]. Regents of the University of California. 
Livingston, E. (1986, September 5). What's new on campus. The Miami Herald, pp. 1D, 2D.

Maxwell, R. and Silverman, P. (1970). Information and esteem: Cultural considerations in the treatment of the aged. Aging and Human Development, 1, 361-394.

Meirhenry, w. (1982). Microcomputers for adult learnerspotentials and perils. Training and Development Journal, 12, 59-66.

Mertz, B. and Stephens, N. (1986). Marketing to older American Consumers. Aging and Human Development, 23, 1. 47-58.

Moody, H.R. (1976). Philosophical presuppositions of education for old age. Educational Gerontology, I, I16.

Okun, M.A. and Elias, C.S. (1977). Cautiousness in adulthood as a function of age and payoff structure. Journal of Gerontology, 32, 451-455.

Plemons, J., Willis, S. and Baltes, P. (1979). Modifiability of fluid intelligence in aging: A shortterm longitudinal training approach. Journal of Gerontology, 4(1), 19-24.

Ramm, D. and Gianturco, D. (1973). Computers and technology: aiding tomorrow's aged. Gerontologist, 13, No. 3, 322-325. 
Rankin, A. (1983). The effect of anxiety on performance in a computer-assisted learning task and its relationship to age and gender. Psychological Abstracts, 71, 54403. Ross, E. (1968). Effects of challenging and supportive instructions in verbal learning in older persons. Journal of Educational Psychology, 59, 261-266.

Rue, V. (1973). Retooling information systems for aging. Aging and Human Development, 4 , No. 4, 361-374.

Salthouse, T.A. and Somberg, B.I. (1982) Isolating the age deficit in speeded performance. Journal of Gerontology, 37, 59-63.

Schaie, K.W. (1978). External validity in the assessment of intellectual development in adulthood. Journal of Gerontology, 33, 696-701.

Stanton, W. (1985). Adults and Computers. T.H.E. Journal, 3, 92-93.

Tamowski, H. (1978) Test-taking behavior of adult learners in a formal education setting. Dissertation Abstracts International, $38(12-\mathrm{A}), 7247$.

Turkle, S. (1984) The Second Self: Computers and the human spirit. New York: Simon and Schuster.

Vinsonhaler, J. and Bass, R. (1972). A summary of ten major studies on CAI drill and practice. Educational Technology, 12, 29-32. 
Wagman, M. (1983). A factor analytic study of the psychological implications of the computer for the individual and society. Behavior Research Methods and Instrumentation, 15 (4), 413-419.

Wallach, M.A. and Kogan, N. (1961). Aspects of judgement and decision making: interrelationships and changes with age. Behavioral Sciences, 6 , 23-36.

Wechsler, D. (1981). Wechsler Adult Intelligence Scale Revised (WAIS-R). New York: Psychological Corporation.

Weisman, S. (1983). Computer Games for the frail elderly. Gerontologist, 23 , No. 4, 361-363.

White, C. and Johnson, D. (1975). Computerized assessment of intelligence: Its differential effects on aged and young individuals. Gerontologist, 15, No. 5, 48.

White, C. and Johnson, D. (1980). Effects of training on computerized test performance in the elderly. Journal of Applied Psychology, 65, No. 3, 357-358.

Willis, S., Bleiszner, R., and Baltes, P. (1981). Intellectual training research in aging: Modification of performance on the fluid ability of figural relations. Journal of Educational Psychology, 73, 4150 . 
VITA

TITLE OF THESIS: Computer Interaction: Its Effect

on Attitude and Performance in older

Adults

FULL NAME: Jane Ansley

PLACE AND DATE OF BIRTH:

Rockville Center, New York, Nov. 3, 1950.

EDUCATION :

Elementary/Secondary:

Dickinson Avenue Elementary, 1956-1962

East Northport Junior High School, 1963-1965

Northport High School - 1966-1968

Colleges/Universities:

State University of New York at Cortland - 1974, B.A. - Psychology

Florida International University - 1987, M.S. - Psychology

MAJOR DEPARTMENT: PSYchology

DATE :

SIGNED: 